\title{
An Evaluation of the Antibacterial Properties of Tormentic Acid Congener and Extracts From Callistemon viminalis on Selected ESKAPE Pathogens and Effects on Biofilm Formation
}

\author{
Tafadzwa Chipenzi, ${ }^{1}$ Genuine Baloyi, ${ }^{1}$ Tatenda Mudondo, ${ }^{1}$ Simbarashe Sithole ${ }^{\mathbb{D}}{ }^{2}{ }^{2}$ \\ Godloves Fru Chi, ${ }^{3}$ and Stanley Mukanganyama $\mathbb{D}^{2}$ \\ ${ }^{1}$ School of Pharmacy, College of Health Sciences, University of Zimbabwe, Mt. Pleasant, Harare, Zimbabwe \\ ${ }^{2}$ Department of Biochemistry, University of Zimbabwe, Mt. Pleasant, Harare, Zimbabwe \\ ${ }^{3}$ University of YAOUNDE 1, P.O. Box 812, Yaoundé, Cameroon
}

Correspondence should be addressed to Stanley Mukanganyama; smukanganyama01@gmail.com

Received 15 August 2020; Revised 26 October 2020; Accepted 28 October 2020; Published 9 November 2020

Academic Editor: Heng Yen Khong

Copyright (c) 2020 Tafadzwa Chipenzi et al. This is an open access article distributed under the Creative Commons Attribution License, which permits unrestricted use, distribution, and reproduction in any medium, provided the original work is properly cited.

\begin{abstract}
ESKAPE pathogens, namely, Enterococcus faecium, Staphylococcus aureus, Klebsiella pneumoniae, Acinetobacter baumannii, Pseudomonas aeruginosa, and Enterobacter species, are responsible for a majority of all healthcare-acquired infections (HAI). The bacteria cause nosocomial infections in immunocompromised patients. Extracts from Callistemon viminalis have been shown to have antibacterial, antifungal, and anti-inflammatory activities. Tormentic acid congener, a pentacyclic triterpene saponin, was isolated from $C$. viminalis leaves. This study aimed to investigate the antibacterial effects of tormentic acid congener and leaf extracts on biofilm formation by A. baumannii, S. aureus, S. pyogenes, and P. aeruginosa. The antibacterial effects were determined by the microbroth dilution method, and ciprofloxacin was used as the standard antibacterial drug. Biofilm formation and detachment assays were performed using crystal violet staining. Production of extracellular polymeric DNA and polysaccharides from biofilms was also determined. Tormentic acid congener showed time-dependent antibacterial activity against $P$. aeruginosa with a MIC of $100 \mu \mathrm{g} / \mathrm{ml}$ and caused significant protein leakage. Antibacterial activity was found when tormentic acid congener was tested against both S. aureus and P. aeruginosa. The MICs were found to be $25 \mu \mathrm{g} / \mathrm{ml}$ and $12.5 \mu \mathrm{g} / \mathrm{ml}$ for $P$. aeruginosa and S. aureus cells, respectively. $S$. pyogenes was found to be susceptible to tormentic acid congener and the hydroethanolic extract with an MIC of $100 \mu \mathrm{g} / \mathrm{ml}$ and $25 \mu \mathrm{g} / \mathrm{ml}$, respectively. A. baumannii was found not to be susceptible to the compound or the extracts. The compound and the extracts caused a significant decrease in the biofilm extracellular polysaccharide content of $S$. pyogenes. The extracts and tormentic acid congener caused detachment of biofilms and decreased the release of extracellular DNA and capsular polysaccharides from biofilms of $P$. aeruginosa and $S$. aureus. Tormentic acid congener and extracts, thus, have significant antibacterial and antibiofilm activities on these selected ESKAPE bacteria and can act as source lead compounds for the development of antibacterial triterpenoids.
\end{abstract}

\section{Introduction}

ESKAPE pathogens are responsible for two-thirds of all healthcare-associated infections [1]. The Infectious Diseases Society of America (ISDA) formulated an acronym ESKAPE to emphasize the group of pathogens that cause hospital infections and effectively "escape" the effects of antibacterial drugs [2]. Gram-positive pathogens, vancomycin-resistant enterococci (VRE) and methicillin- resistant Staphylococcus aureus (MRSA), and Gram-negative pathogens, Pseudomonas aeruginosa and Acinetobacter baumannii as well as extended spectrum-lactamase producing (RSBL) or carbapenem-resistant Enterobacteriaceae (CRE) were used [2]. Approximately 10-15\% of the nosocomial infections on a worldwide scale are caused by $P$. aeruginosa [3]. Nosocomial infections are responsible for hospital-acquired infections largely in immunocompromised patients [4]. 
$K$. pneumoniae and $P$. aeruginosa have been found to cause life-threatening hospital infections in critically ill individuals [5]. These two pathogens have acquired resistance against some of the common antibacterial drugs [6]. K. pneumoniae belongs to the family Enterobacteriaceae [7], and it is one of the most common pathogens associated with hospital-acquired infections [8]. K. pneumoniae naturally inhabits the gastrointestinal tract microbiome of healthy humans and animals [9]. S. aureus is a Gram-positive bacterium carried in the nostrils of approximately $30 \%$ of the people [10]. In most cases, $S$. aureus does not cause any harm; however, in hospitalised immunocompromised people, it may cause infections. These bacteraemia invasions affect people with underlying lung disease, including those on mechanical ventilators and endocarditis, and this can lead to heart failure or stroke [10]. S. pyogenes is a Grampositive, nonmotile, nonspore forming, catalase-negative cocci that occur in pairs or chains [11]. S. pyogenes infections cause pharyngitis and are responsible for up to $33 \%$ of diagnosed cases of sore throat in children and up to $10 \%$ in adults [12]. ESKAPE pathogens have become a major cause of morbidity and mortality all over the world [13]. A. baumannii has the ability of surviving for long periods on hospital surfaces and equipment. This is aided by its ability to develop resistance to multiple antibiotics [14] leading to outbreaks in clinical settings [15].

Biofilm formation is a bacterial strategy to survive under adverse conditions [16]. Bacteria develop resistance to antimicrobial agents as well as thrive in seemingly severe conditions, and this has been attributed to their ability to form biofilms [17]. The production of extracellular polymeric substance (EPS) protects bacterial cells from environmental damage, which leads to these cells developing resistance to antibiotics [18]. There is a continued evolution of dangerous multidrug-resistant bacteria that has led to significant increases in morbidity and mortality due to bacterial infections. Many of the currently prescribed antibacterial drugs have significant adverse side effects [19]. There is urgency for the development of new highly effective and safe antibacterial agents from natural products specifically the complementary and alternative medicines (CAM). The use of different plant sources to search for antibacterial agents has been shown to be a promising approach [20].

Plants of the Callistemon genus are known to possess antifungal, antioxidant, antithrombin, anti-inflammatory, antidiabetic, antibacterial, and herbicidal activities [21]. Callistemon viminalis, also known as bottlebrush, is an ornamental plant which belongs to Myrtaceae family. Extracts from $C$. viminalis have been reported to have various medicinal properties including antibacterial, antifungal, and antioxidant activities [22]. Compounds in C. viminalis have shown antibacterial activity against $S$. aureus and $E$. coli with an inhibitory zone diameter about $16-20 \mathrm{~mm}$ [23]. Phytochemical analysis of $C$. viminalis leaves has demonstrated the presence of phenolic, triterpenoid, flavonoid, saponin, steroid, alkaloid, tannin, carbohydrate, amino acid, and protein compounds [24]. Terpenoids compounds in C. viminalis have shown antimicrobial properties for some bacteria [25]. Triterpenoids are chemical compounds from a class of terpenoids, with chemically characterised six isoprene units and a total of 30 carbon atoms [26]. Triterpenoids are widely distributed secondary metabolites found in many genera of plants and other living organisms, and they exist in different states [27]. Several triterpenes have been isolated from fungi and plant species for investigation into antibacterial agents against $P$. aeruginosa [26]. Several studies have found triterpenes to possess antibacterial effects on $K$. pneumoniae [26].

Tormentic acid can be isolated from several plants which include C. viminalis, Sarcopoterium spinosum [27], and Potentilla chinensis [28] among others. The main objective of the study was to evaluate the antibacterial activity of tormentic acid congener, a triterpenoid isolated from $C$. viminalis, on $K$. pneumoniae, $P$. aeruginosa, S. aureus, $S$. pyogenes, and $A$. baumannii. In addition, we investigated the effects of tormentic acid congener on biofilm production of S. aureus, S. pyogenes, $P$. aeruginosa, and A. baumannii.

\section{Materials and Methods}

2.1. Reagents. The chemicals and solvents used in this study were all obtained from Sigma-Aldrich Chemicals Company (Munich, Germany). Dichloromethane, ethanol, methanol, and water were used for extraction of Callistemon viminalis crude extracts. Dimethyl sulfoxide (DMSO) was used for dissolving the extracts, ciprofloxacin (the standard antibiotic drug), and tormentic acid congener, and 3-(4,5-dimethylthiazol-2-Yl)-2,5-diphenyltetrazolium bromide (MTT) was used as an indicator of cell viability after carrying out assays. The bacterial species $P$. aeruginosa (NCTC 10662), S. pyogenes, K. pneumoniae (ATC700603), A. baumannii (CECT(R) 911), and S. aureus (NCTC 6571) were obtained from Merck (Darmstadt, Germany). Before resuscitation, the cells were kept in a $-80^{\circ} \mathrm{C}$ freezer as $1 \mathrm{ml}$ stock strains in $50 \%$ glycerol. Luria agar base, Miller, was used to plate cells on agar plates, and all the cells were cultured in Luria broth base, Miller. The tormentic acid congener used was isolated from Callistemon viminalis and characterised by NMR and mass spectrometry. All assays were performed in the biological safety cabinet Bioflow-II Labotec, Model 650. The incubator shaker, Model number S1-300 (Jeiotech Co., Korea), and the incubator SI-300 were used for all incubations carried out. For analysis of cell viability using absorbance, a Tecan Genios Pro microplate reader (Tecan Group Ltd, Männedorf, Austria) was used to record the results from a 96-well microwell plate. GraphPad Prism6 (San Diego California, USA) was used to record and analyse the results. For centrifugation, the centrifuge, Rotafix-32 Hettich Zentrifugen Microcent 94-2 Eppendorf centrifuge 541(Sigma-Aldrich Co. Darmstadt, Germany) was used.

2.2. Plant Collection and Preparation. The leaves of Callistemon viminalis were collected in Harare, the University of Zimbabwe, $17.7840^{\circ} \mathrm{S}, 31.0530^{\circ} \mathrm{E}$. The plants had been previously authenticated by a taxonomist from the National Herbarium and Botanic Gardens in Harare, Zimbabwe. The leaves of C. viminalis were separated from the branches and 
predried using a Labcon orbital incubator (Labotech Co., Cape Town, SA) at $60^{\circ} \mathrm{C}$. The dried leaves were ground using a pestle and mortar to produce approximately $4 \mathrm{~g}$ of a powdered sample.

2.3. Preparation of Plant Extracts. The leaves were washed with distilled water then dried in an oven (Memmert, Model $400, \mathrm{D} 06060)$ at $60^{\circ} \mathrm{C}$. The dried leaves were pounded in a traditional mortar and pestle and sieved to obtain a powder. Two solvents were prepared, one with 50\% v/v DCM: $\mathrm{MeOH}$ and the other one with $50 \% \mathrm{v} / \mathrm{v} \mathrm{EtOH}: \mathrm{H}_{2} \mathrm{O}$. The powdered leaves and solvents were mixed in the ration $1: 10$, respectively. The leaves were left soaked in solvents for 3 days after which filtration was performed to obtain the extract. Filtration was done twice, first using cotton wool and using a filter paper thereafter. After filtration, the excess solvent was evaporated using a Buchi RII rotavapor (BÜCHI Labortechnik AG, Postfach, Switzerland), and the crude extract was dried under a fan.

2.4. Column Chromatography on Silica Gel. The leaf extract was run on a column with $100 \%$ hexane initially as the eluting solvent. Batch gradient system column elution was employed starting with a solvent of low polarity to that with high polarity. The batch gradient system was a 20 -step gradient elution with a gradual increase of polarity with $100 \%$ ethyl acetate. Methanol was then added to $100 \%$ EA up to $90 \% \mathrm{EA}$ and $10 \%$ methanol. Fractions of $250 \mathrm{ml}$ were collected and concentrated using a Buchi RII rotary evaporator (BÜCHI Labortechnik AG, Postfach, Switzerland). Thin-layer chromatography was used for the analysis of the collected fractions. The fractions with similar retardation factor values were pooled. The pooled fractions were left to evaporate to dryness for crystals to form. Single spots observed on the developed chromatograms under UV (354 and $365 \mathrm{~nm}$ ) after staining with sulphuring acid were deemed pure and were subjected to NMR analyses.

2.5. NMR Analyses and Determination of the Mass of the Isolated Compound. ${ }^{1} \mathrm{H}$ NMR spectra were recorded at $400 \mathrm{MHz}$ and ${ }^{13} \mathrm{C}$ NMR spectra at $100 \mathrm{MHz}$. The chemical shifts for ${ }^{1} \mathrm{H}$ NMR and ${ }^{13} \mathrm{C}$ NMR were referenced to TMS via residual solvent signals $\left({ }^{1} \mathrm{H}, \mathrm{CDCl}_{3}\right.$ at $7.26 \mathrm{ppm} ;{ }^{13} \mathrm{C}, \mathrm{CDCl} 3$ at $77.36 \mathrm{ppm} ;{ }^{1} \mathrm{H}, \mathrm{DMSO}-d_{6}$ at $2.45 \mathrm{ppm} ;{ }^{13} \mathrm{C}$, DMSO- $d_{6}$ at $39.43 \mathrm{ppm},{ }^{1} \mathrm{H}, \mathrm{CD}_{3} \mathrm{OD}$ at $3.31 \mathrm{ppm}$; and ${ }^{13} \mathrm{C}, \mathrm{CD}_{3} \mathrm{OD}$ at $49.0 \mathrm{ppm}$ ). Two-dimensional (2D) NMR experiments were run using standard pulse sequences. Molecular formulae were determined by electrospray ionization with a 7T hybrid ion trap and a TOF detector running in a positive or negative mode. Tormentic acid congener was identified as a pure compound.

2.6. Antibacterial Susceptibility Tests. Bacteria were grown in Luria broth base, Miller (Sigma-Aldrich), supplemented by casein acid hydrolysate $10 \mathrm{~g} / \mathrm{L}$, yeast extract $5 \mathrm{~g} / \mathrm{L}$, and sodium chloride $5 \mathrm{~g} / \mathrm{L}$. The antibacterial effects of the compound tormentic acid congener as well as those for the
DCM:MeOH and EtOH: $\mathrm{H}_{2} \mathrm{O}$ leaf extracts of C. viminalis were investigated by adapting the microbroth dilution procedure used by Vipra et al. [29]. Briefly, the tormentic acid congener as well as the DCM:MeOH and EtOH: $\mathrm{H}_{2} \mathrm{O}$ leaf extracts of $C$. viminalis were dissolved to give a final concentration of $1 \%$ DMSO and $100 \mu \mathrm{g} / \mathrm{ml}$. The resultant mixtures were serially diluted in a 2 -fold manner with media containing $1 \%$ DMSO up to a minimum concentration of $12.5 \mu \mathrm{g} / \mathrm{ml}$. For all experiments, bacterial cells exponentially growing were standardised using $0.5 \mathrm{McF}$ arland's standard solution to give a cell suspension with a concentration of $1 \times 10^{6} \mathrm{CFU} / \mathrm{ml}$.

Tormentic acid congener, extracts, cells, and Luria broth were diluted into the 96-well microplate wells (Greiner BioOne, Sigma-Aldrich, St. Louis, MO, USA). Each well contained a final volume of $200 \mu \mathrm{l}$. A positive control containing ciprofloxacin (highest concentration of $10 \mu \mathrm{g} / \mathrm{ml}$ ) was set up in each well-containing media and bacterial growth culture. Relevant sterility and negative controls were set up containing media only and media with extract, respectively. Preincubation and postincubation cell density measurements were determined. After postincubation measurements, visualisation of viable cell growth on the plate was investigated by adding $20 \mu \mathrm{l}$ of 3-(4,5-dimethylthiazol-2)-2, 5 -diphenyltetrazolium bromide (MTT) solution $(1 \mathrm{mg} / \mathrm{ml})$ to each well. The 96-well microplate was then covered and placed in an incubator for 2 hours.

2.7. Time-Kill Assays of Tormentic Acid Congener on $P$. aeruginosa. The time-kill assays for tormentic acid congener on $P$. aeruginosa were performed in LB culture medium after carrying out serial dilutions starting from 100 to $12.5 \mu \mathrm{g} / \mathrm{ml}$. After standardisation of cells using the 0.5 McFarland solution, ciprofloxacin was used as a control standard and untreated cells were used as a positive control. Aliquots of diluted cell suspension and tormentic were added to a microplate wells plate in equal volumes to produce a total volume of $200 \mu \mathrm{l}$. The microplate was incubated, and then, the absorbance was measured under suitable conditions for varied time intervals $(0,8,10,24,26$, 28,30 , and 32 hours). The results of the absorbance representing cell densities were used to plot time-kill graphs for $100 \mu \mathrm{g} / \mathrm{ml}, 50 \mu \mathrm{g} / \mathrm{ml}, 25 \mu \mathrm{g} / \mathrm{ml}, 12.5 \mu \mathrm{g} / \mathrm{ml}$, and the control. MTT was then added to the 96-well microplate to determine cell viability. The bactericidal effect was obtained from observing the graph with a lethality percentage of $90 \%$ for 6 hours, which is equivalent to $99.9 \%$ of lethality for 24 hours. This method was used to further confirm the MIC of tormentic acid congener on $P$. aeruginosa.

2.8. Effects of Combining Ciprofloxacin and Tormentic Acid Congener on P. aeruginosa. The checkerboard assay was used to determine the effects of combining ciprofloxacin and tormentic acid congener on P. aeruginosa in consideration of their individual effects against this bacterium. This assay was aimed at determining and observing the presence of antagonism, synergism, and zero interaction between tormentic acid congener and ciprofloxacin [30]. Since there was 
$88 \%$ agreement between time-kill and checkerboard assay, this method was used to confirm the effects of tormentic acid congener on $P$. aeruginosa as shown by time-kill assays [31] and to calculate the fractional inhibitory concentration. After standardisation of cells using the $0.5 \mathrm{McF}$ arland scale, $100 \mu \mathrm{l}$ of the inoculum was added to each well in a sterile 96well microplate. Equal volumes of $50 \mu \mathrm{l}$ tormentic acid congener and $50 \mu \mathrm{l}$ ciprofloxacin were added to the wells. The plate was incubated at $37^{\circ} \mathrm{C}$, and absorbance of the cells was measured at varied time intervals $(0,8,10,24,26,28,30$, and32 hours). The results of the absorbance were used to plot time-kill graphs for $100 \mu \mathrm{g} / \mathrm{ml}, 50 \mu \mathrm{g} / \mathrm{ml}, 25 \mu \mathrm{g} / \mathrm{ml}, 12.5 \mu \mathrm{g} /$ $\mathrm{ml}$, and control. The fractional inhibitory index (FICI) was calculated with the concentrations in the first nonturbid well found in each row and column of the microplate after extrapolating line graphs [32]. The different combinations are categorised as synergistic if FICI is $\leq 0.5$, antagonistic when FICI $>4$, and indifferent if $0.5<$ FICI $\leq 4$ [32]. The FICI was calculated using the following equation [32]:

$$
\mathrm{FICI}_{A / B}=\frac{\operatorname{MICA}(\text { combination })}{\operatorname{MICA}(\text { alone })}+\frac{\operatorname{MICB} \text { (combination) }}{\operatorname{MICB} \text { (alone })} \text {. }
$$

2.9. Effects of Tormentic Acid Congener on Protein Leakage. From precultured $P$. aeruginosa cell suspension, a volume of $200 \mu \mathrm{l}$ was subcultured in $200 \mathrm{ml}$ of Luria broth base in a 1-litre container, and the cells were incubated overnight at $37^{\circ} \mathrm{C}$ at $100 \mathrm{rpm}$. The subcultured cells were centrifuged at $3500 \mathrm{rpm}$ for 4 minutes, and the supernatant was removed. The pellet of $P$. aeruginosa cell suspension was diluted with $0.9 \%$ normal saline to produce absorbance of 1.5 OD using a centrifuge (Rotafix-32 Hettich Zentrifugen Microcent 94-2 Eppendorf centrifuge 541). To triplicates of labelled tubes A, B, C, D, and E, $6 \mathrm{ml}$ of diluted cells was added. To tube A, $150 \mu \mathrm{l}$ of tormentic acid congener was added to make a final concentration of $100 \mu \mathrm{g} / \mathrm{ml}$. To tube B, $2.4 \mu \mathrm{l}$ of ciprofloxacin was added to make up a final concentration of $0.16 \mu \mathrm{g} / \mathrm{ml}$. To the control tube $\mathrm{C}$, $1200 \mu \mathrm{l}$ of SDS was added, to tube D, $180 \mu \mathrm{l}$ of DMSO was added, and untreated cells were added to tube $\mathrm{E}$. The tubes were centrifuged at $3500 \mathrm{rpm}$ in the centrifuge for 4 minutes, and the pellets were discarded; the supernatants were used for protein determination assay. An exact volume of $150 \mu \mathrm{l}$ of the supernatants was separately added to a labelled sterile 96-well plate. A calibration curve of concentration $0-50 \mu \mathrm{g} / \mathrm{ml}$ of the BSA stock was made. To each well, $150 \mu \mathrm{l}$ of Bradford's reagent was added, and the optical densities of the wells were read at $590 \mathrm{~nm}$ using a Tecan Genios Pro microplate reader (Tecan Group Ltd, Männedorf, Austria).

\subsection{Effect of Extracts and Tormentic Acid Congener on Biofilm Formation}

2.10.1. Biofilm Formation Procedure. For this assay, precultured cells were then centrifuged at $3500 \mathrm{rpm}$ for 15 minutes in a Rotafix-32 Hettich Zentrifugen. The supernatant of the centrifuged cell culture was discarded, and
$20 \mathrm{ml}$ of $0.5 \mathrm{M}$ phosphate-buffered saline prepared from sodium dihydrogen phosphate as the acidic salt and disodium hydrogen phosphate as the basic salt at $\mathrm{pH} 7.20$ was used to wash the cells. The cell suspension was centrifuged again at $3500 \mathrm{rpm}$ for 15 minutes, the supernatant was discarded, and $5 \mathrm{ml}$ of sterile media was added and hand shaken to the dissolve the cell pellet in the media. A $2 \mathrm{ml}$ volume of standardised cells was added to each well of a 24well plate (Sigma-Aldrich Co. Darmstadt, Germany). Thereafter, the cells were allowed to adhere to the wells by incubating the cells at $37^{\circ} \mathrm{C}$ for 2 hours. During the incubation period, stock concentrations of test solutions were prepared to give a final concentration of $100 \mu \mathrm{g} / \mathrm{ml}$ and $10 \mu \mathrm{g} / \mathrm{ml}$ for ciprofloxacin. After the incubation, $500 \mu \mathrm{l}$ of antibacterial test solutions was added to the wells and left for further incubation for 72 hours at $37^{\circ} \mathrm{C}$ in a humid nonshaking incubator. After incubation, the contents of each well were gently discarded, and the plate was gently washed three times with $0.5 \mathrm{M}$ phosphate buffer saline at $\mathrm{pH}$ 7.20. After washing, the plate was inverted on a paper towel for 15 minutes to drain off excess liquid, and the biofilms were subsequently fixed by incubating the plate at $60^{\circ} \mathrm{C}$ for 1 hour in an oven. After incubation, the biofilms were quantified as follows: $2.5 \mathrm{ml}$ of $0.1 \%$ crystal violet was added to each well, the plate was further incubated at room temperature for 20 minutes before the crystal violet was discarded, and the plate was gently washed with sterile water. The plate was left to dry for overnight; then, $2.5 \mathrm{ml}$ of absolute alcohol $99.9 \%$ was added to the wells of the plate. From each well, $200 \mu$ l was transferred to a 96-well plate, and optical density readings of the plate were measured at $590 \mathrm{~nm}$ using a Tecan Genios Pro microplate reader (Tecan Group Ltd, Männedorf, Austria).

\subsubsection{Effect of Extracts and Tormentic Acid Congener on} Biofilm Detachment. Precultured S. pyogenes and A. baumannii cells were centrifuged at $3500 \mathrm{rpm}$ for 15 minutes. The supernatant of the centrifuged cell culture was discarded, and $20 \mathrm{ml}$ of $0.5 \mathrm{M}$ phosphate-buffered saline prepared from sodium dihydrogen phosphate as the acidic salt and disodium hydrogen phosphate as the basic salt at $\mathrm{pH}$ 7.20 was used to wash the cells. The cell suspension was centrifuged again at $3500 \mathrm{rpm}$ for 15 minutes, the supernatant was discarded, and $5 \mathrm{ml}$ of sterile media was added and hand shaken so as the dissolve the cell pellet in the media. A $2 \mathrm{ml}$ volume of standardised cells were added to each well of a 24well plate (Sigma-Aldrich Co. Darmstadt, Germany). The cells were allowed to adhere to the wells of a 24 -well microplate by incubating the cells in a shaking incubator at $37^{\circ} \mathrm{C}$ for 2 hours. After 2 hours of incubation, the microplate is incubated in a nonshaking incubator for 72 hours. After incubation, $1.2 \mathrm{ml}$ of $100 \mu \mathrm{g} / \mathrm{ml}$ of antibacterial test solutions and $1.2 \mathrm{ml}$ of Tween 20 detergent solution were added to the plates. The plate was incubated in a nonshaking incubator, at $37^{\circ} \mathrm{C}$ for 2 hours; thereafter, the biofilm was quantified.

2.10.3. Effect of Extracts and Tormentic Acid Congener on Capsular Polysaccharide Content of Biofilms. The extracellular polysaccharide of the extra polymeric substance was 
quantified using the phenol-sulphuric acid method. For the capsular polysaccharide analysis, precultured $S$. pyogenes and $P$. aeruginosa cells were standardised and added as $4 \mathrm{ml}$ volumes to 5 sterilised $50 \mathrm{ml}$ centrifuge tubes with $100 \mu \mathrm{l}$ of $100 \mu \mathrm{g} / \mathrm{ml}$ of $C$. viminalis extracts and tormentic acid congener as well as $0.64 \mu \mathrm{g} / \mathrm{ml}$ of the positive control, ciprofloxacin. The cells were further incubated in a shaking incubator at $37^{\circ} \mathrm{C}$ for 4 hours. After the incubation period, cells were separated by centrifugation at $4000 \mathrm{rpm}$ for 15 minutes. The procedure was repeated thrice with chilled phosphate-buffered saline of $\mathrm{pH}$ 7.2. After centrifugation, the cells were suspended in $450 \mu \mathrm{l}$ of autoclaved distilled water, and an equal volume of $450 \mu \mathrm{l}$ of saturated phenol was added and then heated in a waterbath at $65^{\circ} \mathrm{C}$ for 20 minutes. For each sample, $300 \mu \mathrm{l}$ was taken in triplicate and added to sterile Eppendorf tubes. To each tube, $150 \mu \mathrm{l}$ chloroform was added, and the solution was mixed intensely by vortexing. The cell suspension mixture was then centrifuged, and $50 \mu \mathrm{l}$ of the supernatant was collected and distributed into their respective wells of a flat-bottomed microplate. A standard curve, using $50 \mu \mathrm{l}$ mannose at concentrations from $100 \mu \mathrm{g} / \mathrm{ml}$ to $6.30 \mu \mathrm{g} / \mathrm{ml}$ as well as a control with no mannose, was prepared. In each well, $150 \mu \mathrm{l}$ of concentrated sulphuric acid and $30 \mu \mathrm{l}$ of $5 \%$ phenol were also added, and the microtitre plate was put in a static waterbath of $90^{\circ} \mathrm{C}$ for 5 minutes. After heating, the plate was allowed to cool at room temperature for a further 5 minutes and wiped dry; absorbance was read at $492 \mathrm{~nm}$ using a Stat Fax 2100 microplate reader (Awareness Technologies Inc, Westport, United States of America).

2.10.4. Effects of Tormentic acid Congener on Extracellular DNA Content in Static Biofilms. The effect of tormentic acid congener, DCM:MeOH extract, and EtOH: $\mathrm{H}_{2} \mathrm{O}$ extracts on extracellular DNA production in static biofilm formation was studied using a method developed by Hawser and Douglas [33]. Briefly, precultured $P$. aeruginosa cells were centrifuged at $3500 \mathrm{rpm}$ for 15 minutes. The pellet was washed using $0.5 \mathrm{M}$ phosphate-buffered saline $\mathrm{pH}$ 7.2. The tormentic acid congener, DCM:MeOH extract, and EtOH: $\mathrm{H}_{2} \mathrm{O}$ extract were dissolved in $1 \%$ DMSO and Luria broth to give a final concentration of $12.5 \mu \mathrm{g} / \mathrm{ml}$. Of the resulting solution, $500 \mu \mathrm{l}$ was taken and added to the wells of a 24-well microplate. Positive control was set up using ciprofloxacin at a concentration of $0.80 \mu \mathrm{g} / \mathrm{ml}$. Negative control of media and cells was also run in parallel.

\section{Results and Discussion}

3.1. Isolation and of Identification of Tormentic Acid Congener. The following spectral characteristics were obtained: white powder; ${ }^{1} \mathrm{H}-\mathrm{NMR}$ (DMSO, $\left.400 \mathrm{MHz}\right) \delta(\mathrm{ppm}): 5.14(1 \mathrm{H}, b r$ $s, \mathrm{H}-12), 3.49(1 \mathrm{H}, \mathrm{m}), 2.74(1 \mathrm{H}, d, J=9.2, \mathrm{H}-3), 2.12(1 \mathrm{H}, d$, $J=11.2, \mathrm{H}-18), 2.00-1.20\left(\mathrm{CH}_{2}\right.$ and $\mathrm{CH}$ region $), 1.04(3 \mathrm{H}, s$, $\mathrm{H}-27), 0.93(3 \mathrm{H}, s, \mathrm{H}-23), 0.93(3 \mathrm{H}, s, \mathrm{H}-25), 0.92(3 \mathrm{H}, s$, $\mathrm{H}-30), 0.83(3 \mathrm{H}, d, J=6.4, \mathrm{H}-29), 0.77(3 \mathrm{H}, d, \mathrm{H}-5), 0.75(3 \mathrm{H}$, $s, \mathrm{H}-26)$, and $0.72(3 \mathrm{H}, s, \mathrm{H}-24) .{ }^{13} \mathrm{C} \mathrm{NMR}$ (DMSO, $100 \mathrm{MHz}) \delta$ (ppm): 178.7 (C-28), 138.7 (C-13), 124.9 (C-12), 82.7 (C-3), 70.2 (C-20), 67.6 (C-2), 55.2 (C-5), 52.8 (C-18),
47.5 (C-17), 47.5 (C-1), 47.4 (C-9), 46.4 (C-14), 40.5 (C-10), 39.4 (C-8), 39.3 (C-4), 38.9 (C-21), 38.8 (C-19), 36.8 (C-22), 33.0 (C-7), 30.6 (C-16), 29.3 (C-23), 27.9 (C-15), 23.7 (C-27), 23.4 (C-11), 21.5 (C-30), 18.6 (C-6), 17.6 (C-24), 17.5 (C-26), 17.4 (C-24), 16.9 (C-29), and 16.9 (C-25).

The principle active showed the molecular ion $\left(\mathrm{M}^{+}\right)$at $\mathrm{m} / \mathrm{z}$ 488 , which agrees with the molecular formula $\mathrm{C}_{30} \mathrm{H}_{48} \mathrm{O}_{5}$. The ${ }^{1} \mathrm{H}-\mathrm{NMR}$ spectrum showed the presence of six singlet methyls and two doublet methyls, which were characteristic of the ursene skeleton, and exhibited signals of an olefinic proton $(\delta$ 5.14). The spectrum also showed a singlet at $\delta 3.49(\mathrm{~m})$ and two oxygen-bearing methine protons suggestive of the $2 \alpha, 3 \beta, 19 \alpha$ trihydroxy structure. These results indicated that the compound was an ursane-type triterpene. Furthermore, ${ }^{13} \mathrm{C}$ NMR data substantiated the presence of a pair of olefinic carbons $(\delta$ $138.7(\mathrm{C}-13)$ and $\delta 124.9(\mathrm{C}-12))$, a carboxylic acid group $(\delta$ 178.7 (C-28)), and three hydroxylated carbons $(\delta 82.7$ (C-3), $70.2(\mathrm{C}-20)$, and $67.6(\mathrm{C}-2))$ on the ursene structure. The structure was determined to be $2 \alpha, 3 \beta, 20 \beta$-trihydroxyurs-12en-28-oic acid [34].

3.2. Antibacterial Susceptibility Tests. The antibacterial effect of $C$. viminalis leaves was first screened by testing the effects of methanolic and ethanolic crude extracts on all five bacteria using the microbroth dilution assay. After incubation with MTT, the number of viable cells was determined spectrophotometrically. The antibacterial susceptibility tests showed S. aureus and K. pneumoniae (Figure 1) to be more susceptible to both extracts of $C$. viminalis than $P$. aeruginosa. These results are consistent with those of other studies which suggest that Gram-negative bacteria are less susceptible to xenobiotics than Gram-positive bacteria [35]. The DCM:MeOH extract and EtOH: $\mathrm{H}_{2} \mathrm{O}$ extract of C. viminalis may, however, have a broader spectrum of antibacterial activity as they exhibited activity against both Gram-positive and Gram-negative bacterial species.

Another important finding was that all extracts of C. viminalis had a minimal antibacterial effect against $P$. aeruginosa matching those observed in an earlier study by Chitemerere and Mukanganyama [36]. P. aeruginosa has a thick outer membrane that is highly hydrophobic, and this membrane provides a permeability barrier to the extract. The determination of MIC using C. viminalis crude extracts was an indicator of the effect of various triterpenes, flavonoids, and alkaloids that have antibacterial activity which are present in the plant leaves. At the highest concentration of tormentic acid congener $(100 \mu \mathrm{g} / \mathrm{ml})$, there was complete inhibition of the bacterial activity of $P$. aeruginosa.

Extracts of $C$. viminalis were also tested for antibacterial activity against $S$. pyogenes and A. baumannii. The $50 \% \mathrm{v} / \mathrm{v}$ EtOH: $\mathrm{H}_{2} \mathrm{O}$ extract of $C$. viminalis and tormentic acid congener proved were shown to have the most potent antibacterial effects against S. pyogenes at $100 \mu \mathrm{g} / \mathrm{ml}$. Extracts of $C$. viminalis and tormentic acid congener did not have much inhibitory effects against $A$. baumannii, indicating intrinsic resistance of this bacterial strain. Antimicrobial resistance of A. baumannii is mainly due to reduced permeability of the outer membrane caused by loss or low porin expression, increased expression of 


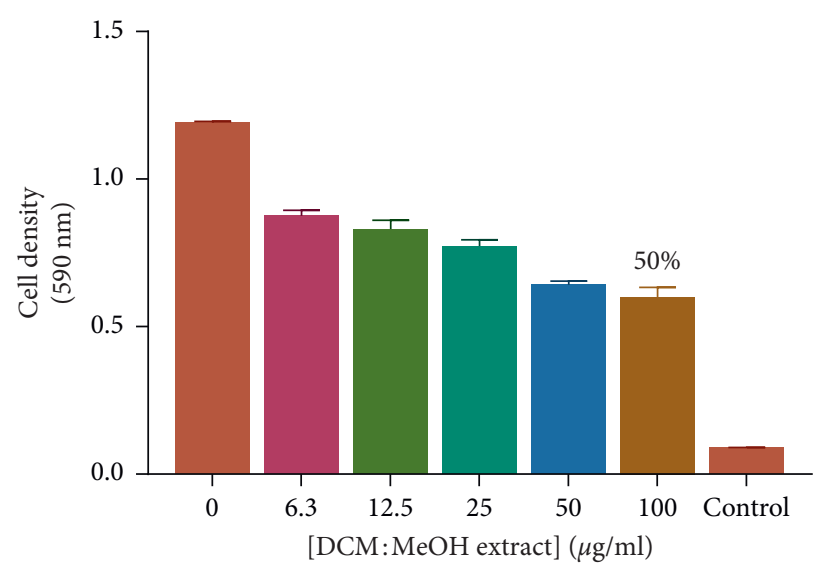

(a)

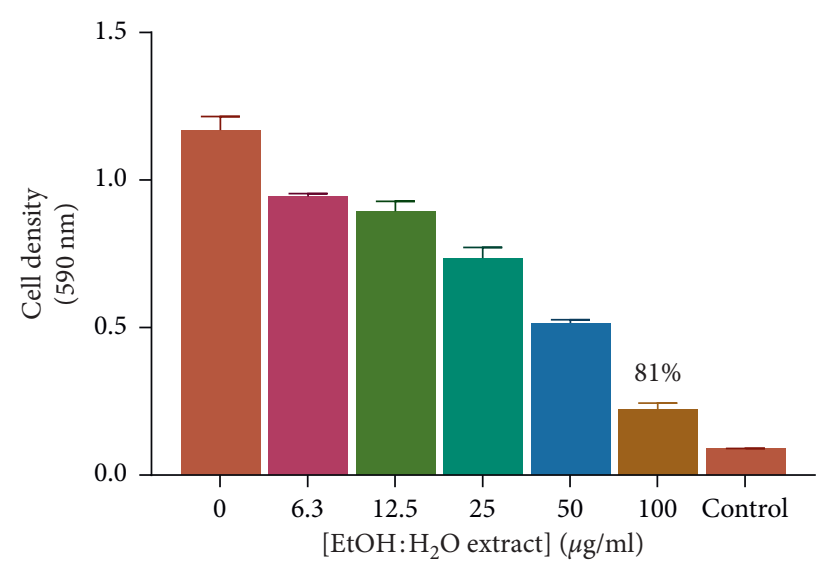

(b)

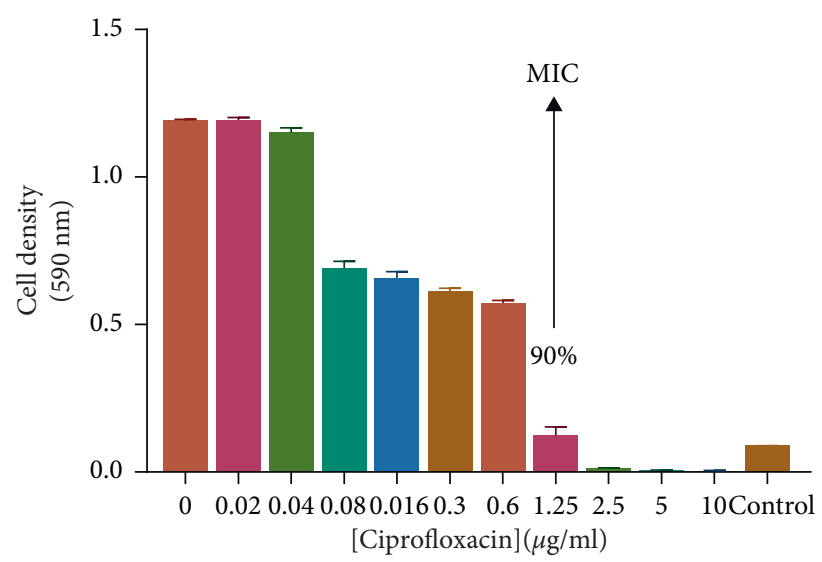

(c)

Figure 1: The effects of exposing on K. pneumoniae to extracts from Callistemon viminalis. Results of the microbroth dilution assay results are shown for (a) DCM:MeOH extract, (b) EtOH: $\mathrm{H}_{2} \mathrm{O}$ extract, and (c) ciprofloxacin. The error bars represent standard deviation from the mean of 4 repeat measurements.

multidrug efflux pumps, and mutations altering targets or different cellular functions [37]. The antibacterial effects of $\beta$-naphthoflavone on A. baumannii were also tested and were shown to have an inhibitory effect of $68 \%$. Flavonoids are formed as antimicrobial barriers in plants response to microbial infection [38]. Flavonoids target the bacterial cytoplasmic membranes causing membrane fusion between microorganisms, resulting in leakage of intramembranous materials which promotes aggregation. Also, large bacterial aggregate clumps are more easily detected by the innate immune system compared to those bacteria in biofilm [39]. The poor activity of cell membrane active flavones against Grampositive S. pyogenes might be because of poor penetration to the cell membrane of the bacteria due to presence of a thick layer of peptidoglycan in their cell walls which act as a barrier. Tiwari and colleagues showed that herbal compounds are generally antibacterial agents but show better antimicrobial activity when used in synergy with other antibiotics [37].

\subsection{Time-Kill Kinetics of Tormentic Acid Congener on} P. aeruginosa. The time-kill assay was carried out to determine the capacity of tormentic acid congener to kill the bacterium $P$. aeruginosa in relation to time. A range of five concentrations
$(100-0 \mu \mathrm{g} / \mathrm{ml})$ were used, together with ciprofloxacin as a control. The antibacterial effect of tormentic acid congener on $P$. aeruginosa was shown to be time-dependent. At the highest concentration of tormentic acid congener $100 \mu \mathrm{g} / \mathrm{ml}$, there was a complete inhibition of the bacterial activity of $P$. aeruginosa (Figure 2(a)). At $100 \mu \mathrm{g} / \mathrm{ml}$, tormentic acid congener completely inhibited the growth of $P$. aeruginosa cells. The antibacterial activity of tormentic acid congener was efficient with $50 \mu \mathrm{g} / \mathrm{ml}$ inhibiting the growth of $P$. aeruginosa during the first 10 hours. The positive control ciprofloxacin showed an inhibition of the growth of $P$. aeruginos a cells from a minimum concentration of $0.32 \mu \mathrm{g} / \mathrm{ml}-10 \mu \mathrm{g} / \mathrm{ml}$. There was a subsequent increase in cell growth in the wells with $0.16,0.08,0.04$, and $0.02 \mu \mathrm{g} / \mathrm{ml}$ of tormentic acid congener, although the rate of cell growth was lower than that of the standard control. The time-kill assay of ciprofloxacin further confirmed the minimum inhibitory concentration of $0.32 \mu \mathrm{g} / \mathrm{ml}$ against $P$. aeruginosa (Figure 2(b)).

\subsection{Effects of Combining Tormentic Acid Congener and} Ciprofloxacin on the Growth of $P$. aeruginosa. Antibacterial combinations have been extensively researched to determine the synergistic combination and interactions between potential antibacterial agents to 


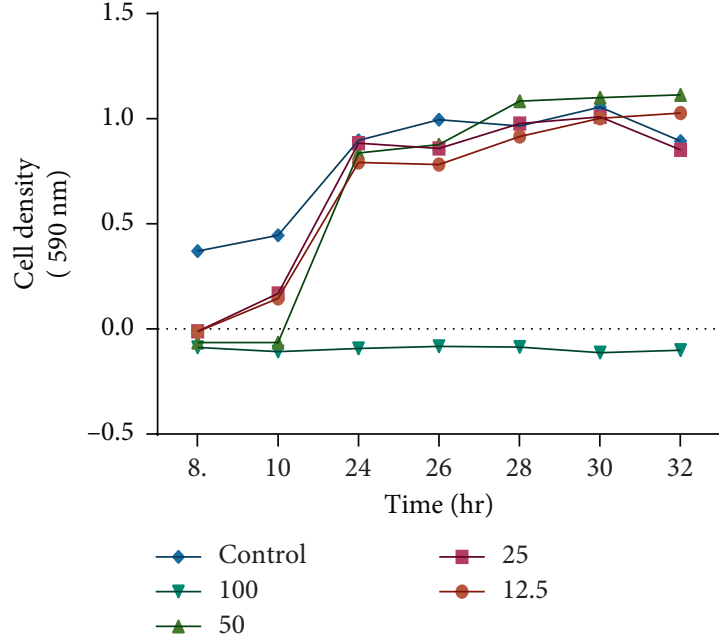

(a)

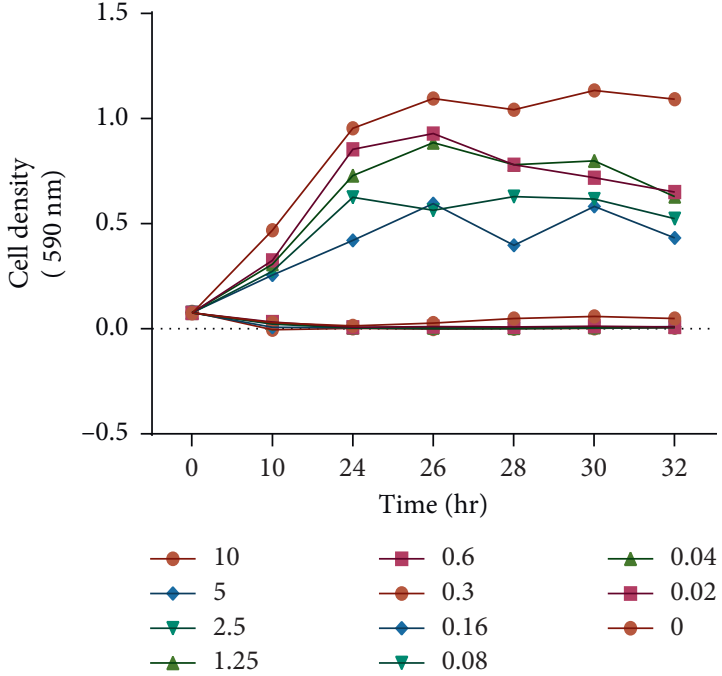

(b)

Figure 2: Time-kill curves of $P$ aeruginosa cells after exposure to tormentic acid congener (a) and ciprofloxacin (b). Cells were standardised to $1 \times 106 \mathrm{cfu} / \mathrm{ml}$. They were incubated with the compounds at 2 -fold increasing concentrations for 32 hours and incubated at $37^{\circ} \mathrm{C}$.

optimise the efficacy and potency of antibacterial drugs [40]. Synergism occurs when there is a decrease in the viable organism as an outcome of combining two antibiotics when compared to the effect of using the most effective antibiotic alone [41]. The checkerboard combination assay was carried out to determine the effect of combining ciprofloxacin and tormentic acid congener. For tormentic acid congener, the MIC, $1 / 2$ MIC, $1 / 4$ MIC, and $1 / 8$ MIC was used. The concentrations of ciprofloxacin used were MIC 0.32, 0.16, 0.08, 0.04, and 0.02. As shown in Figure 3, tormentic acid congener decreased the MIC of ciprofloxacin from $0.3 \mu \mathrm{g} / \mathrm{ml}$ to $0.16 \mu \mathrm{g} / \mathrm{ml}$ at the MIC concentration of $100 \mu \mathrm{g} / \mathrm{ml}$. The other concentrations of tormentic acid congener did not have a significant effect on the MIC of ciprofloxacin.

Combining concentrations of $100 \mu \mathrm{g} / \mathrm{ml}$ of tormentic acid congener and $0.016 \mu \mathrm{g} / \mathrm{ml}$ of ciprofloxacin was indifferent at $37^{\circ} \mathrm{C}$ for 3 hours incubation because the calculated FICI was 0.5016 . Some in vitro tests have indicated that terpenes show ineffective antimicrobial activity when used as a single compound but are more effective when used in combination with other antibacterial agents [42]. Another study showed synergism when triterpenes were combined with ciprofloxacin and tested on E. coli [43]. Several diterpenoids, terpenoids, and sesquiterpenoids have been found to act synergistically with different antibiotics [44]. Similarly, tormentic acid congener might be able to work in synergy with other antibiotics regardless of its inability to work in synergy with ciprofloxacin. Some of the antibacterial drugs that show synergistic or additive effects when combined with triterpenoids include methicillin and vancomycin [45].

3.5. Determination of the Effects of Tormentic Acid Congener on Membrane Integrity Using the Protein Leakage Determination Assay. The proposed mechanism of action of tormentic acid congener was protein leakage, and this was determined by exposing the bacteria to the compound and determining the amount of protein using the Bradford assay. The mechanism of action of ciprofloxacin against bacteria is not cell lysis, and therefore, ciprofloxacin did not cause significant cell lysis in P. aeruginosa in comparison to the unexposed cells. As shown in Figure 4, tormentic acid congener caused cell lysis in $P$. aeruginosa, and this exposure resulted in significant protein leakage. The positive controls were $1 \%$ SDS that caused significant protein leakage in $P$. aeruginosa. Exposure to ciprofloxacin did not result in protein leakage, and this was in correlation with the research that was performed by Jedrey et al. [46]. SDS caused notable cell lysis in P. aeruginosa cells [47], which resulted in protein leakage.

Studies have shown that some phytochemicals including terpenes affect the stability of the cell membrane in bacterial cells, and these include p-cymene, carvacrol, and thymol [43]. Carvacrol for instance causes functional and structural damage and disruption of the membrane Gram-negative pathogens [43]. Thymol merges to the polar headgroups that make up the lipid bilayers, and it induces alterations to the cell membrane affecting its permeability [43]. Other terpenes that have effectively damaged bacterial cells of $S$. aureus and E. coli, respectively, are citronellol and citronellal, and their permeabilisation to the membrane or cell wall are related to alterations on their physicochemical properties [48].

3.6. Effects of Extracts and Tormentic Acid Congener on Species on Biofilm Production. Biofilm formation is a major resistance mechanism displayed by bacteria. Both $S$. pyogenes and A. baumannii can form biofilms $[49,50]$. The extracellular polymeric substance is composed of polysaccharide, proteins, and extracellular DNA [51]. Biofilm formation activities were determined using $0.1 \%$ crystal violet staining of adherent biofilm, and the results are shown in Figure 5. To evaluate the effect of C. viminalis extracts, tormentic acid congener, and 


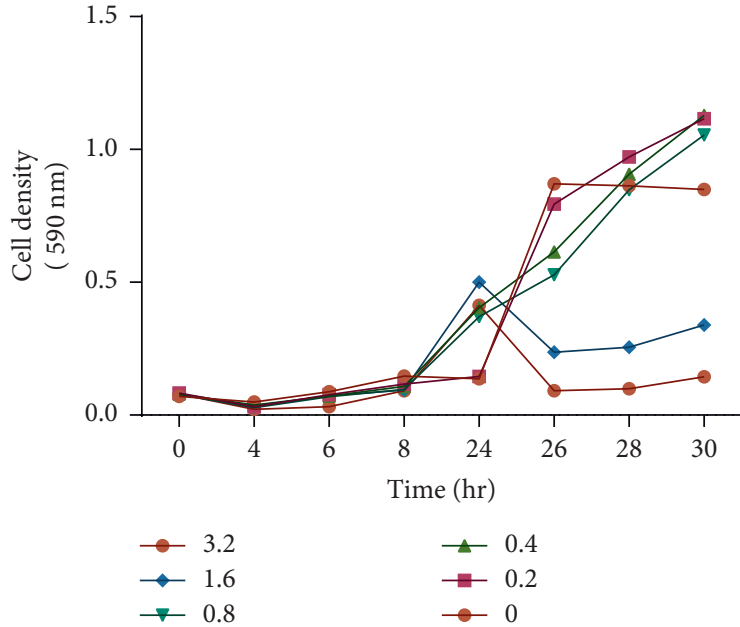

(a)

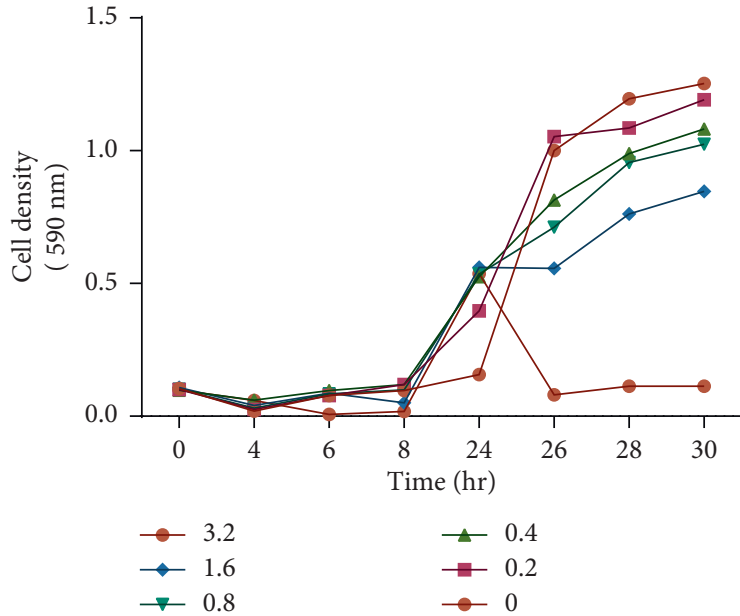

(c)

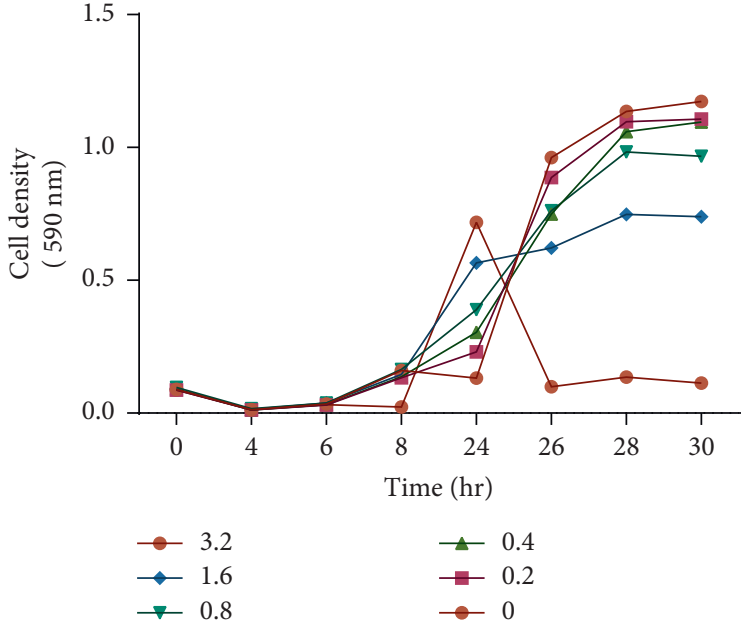

(b)

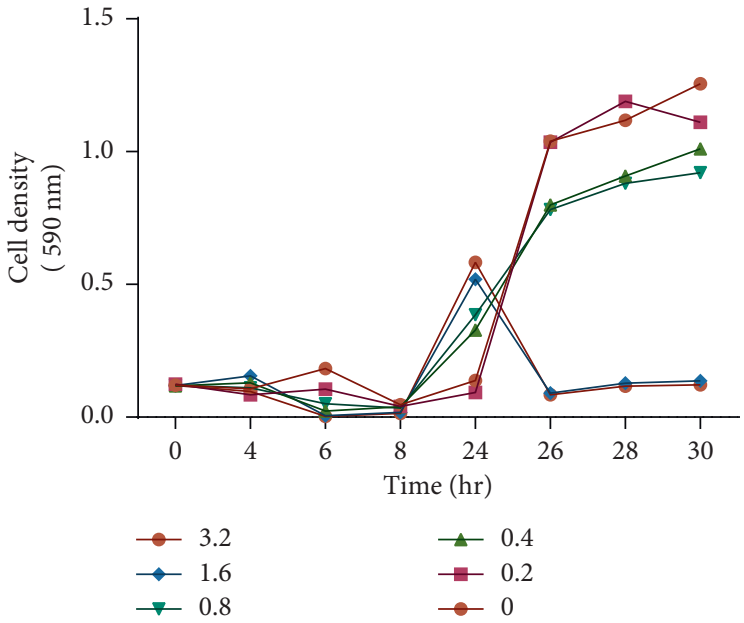

(d)

Figure 3: The effects of combining tormentic acid congener and ciprofloxacin on $P$ aeruginosa. The effect of ciprofloxacin on $P$ aeruginosa together with a concentration of (a) $0 \mu \mathrm{g} / \mathrm{ml}$, (b) $25 \mu \mathrm{g} / \mathrm{ml}$, (c) $50 \mu \mathrm{g} / \mathrm{ml}$, and (d) $100 \mu \mathrm{g} / \mathrm{ml}$ of tormentic acid congener.

ciprofloxacin against biofilm formation, the antibiofilm agents were incubated together with the bacterial strains in a 24 -well plate for 72 hours at $37^{\circ} \mathrm{C}$. Ciprofloxacin inhibited biofilm formation by $80 \%$ and $85 \%$ in S. pyogenes and A. baumannii, respectively. Tormentic acid congener and $C$. viminalis extracts had no significant effect on biofilm formation inhibition for both test bacterial strains. Biofilms account for over $80 \%$ of microbial infections in the human body [52]. Bacterial cells in biofilms are 10-1000 times less susceptible to antimicrobial agents compared to their planktonic counterparts due to the physical impedance leading to poor diffusion of the drugs into the biofilm [53]. Also, bacteria embedded in a biofilm can evade the host immune system, therefore, contributing to its resistance mechanism [54]. Most bacteria exist within biofilms encased in an extracellular polymeric substance made up of biopolymers [55].

3.6.1. Effects of Extracts and Tormentic Acid Congener Detachment of Preformed Biofilms. The standard antibiotic drug ciprofloxacin showed the least antiadhesion properties on the already formed biofilms in both test bacteria, S. pyogenes and A. baumannii (Figure 6). Ciprofloxacin only caused the detachment of $28 \%$ of the biofilm formed in S. pyogenes and had no detachment effect on biofilms formed by A. baumannii. Tormentic acid congener and $C$. viminalis extracts had no biofilm formation inhibitory effect but rather cause detachment of already formed biofilms in both $S$. pyogenes and A. baumannii. Lack of inhibitory effect on biofilm formation could be attributed to the low antibacterial activity of the test antimicrobial agents. A. baumannii proliferated at $100 \mu \mathrm{g} / \mathrm{ml}$ of test antibacterial agents and produced biofilms at same concentrations increasing its mechanisms of resistance. Ciprofloxacin showed antibiofilm activity at $10 \mu \mathrm{g} / \mathrm{ml}$ of the drug. The subminimum inhibitory concentration of ciprofloxacin was supposed to be used to ensure bacterial species were not killed by high ciprofloxacin concentrations. Ciprofloxacin had no biofilm detachment activity against test bacterial species as shown by tormentic acid congener and $C$. viminalis extracts.

Cell surface hydrophobicity is a crucial factor for biofilm formation and stabilisation in biofilm-forming bacteria [56]. 


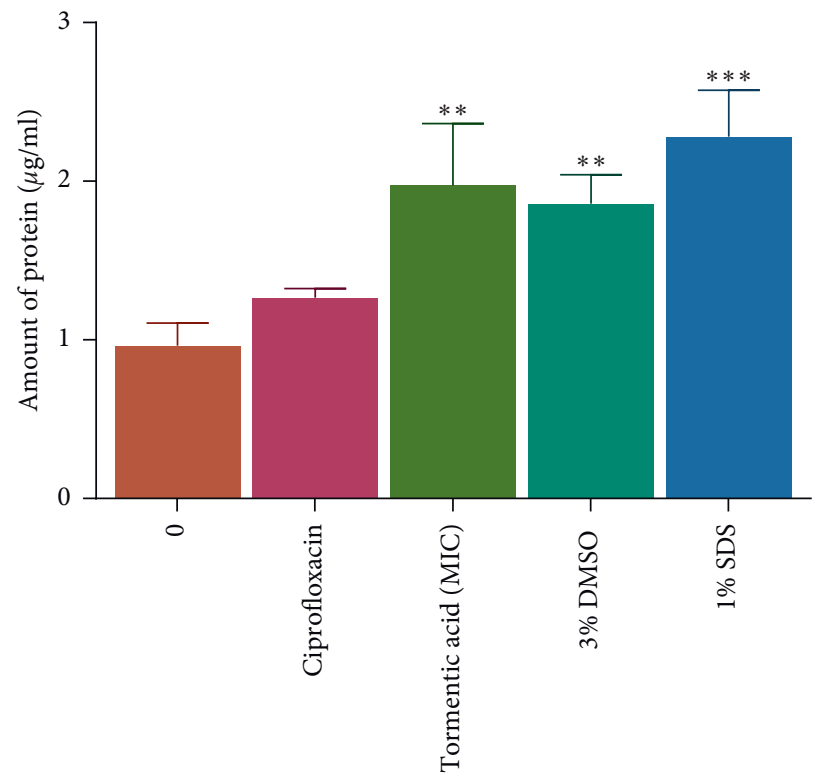

Figure 4: The effect of exposing $P$ aeruginosa to ciprofloxacin $(0.016 \mu \mathrm{g} / \mathrm{ml})$ and tormentic acid congener $(100 \mu \mathrm{g} / \mathrm{ml})$ on release of intracellular protein in $P$. aeruginosa. The absorbance intensities of treated $P$ aeruginosa cells were measured at $590 \mathrm{~nm}$. Results are presented as mean $(n=3) \pm$ standard deviations. Asterisk denotes a significant difference $\left({ }^{* *} P<0.01\right)$.

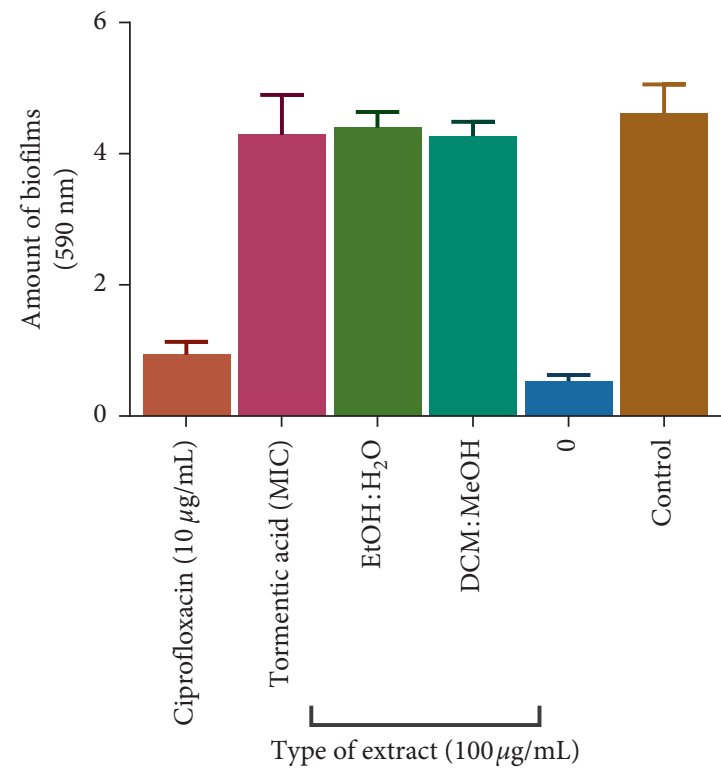

(a)

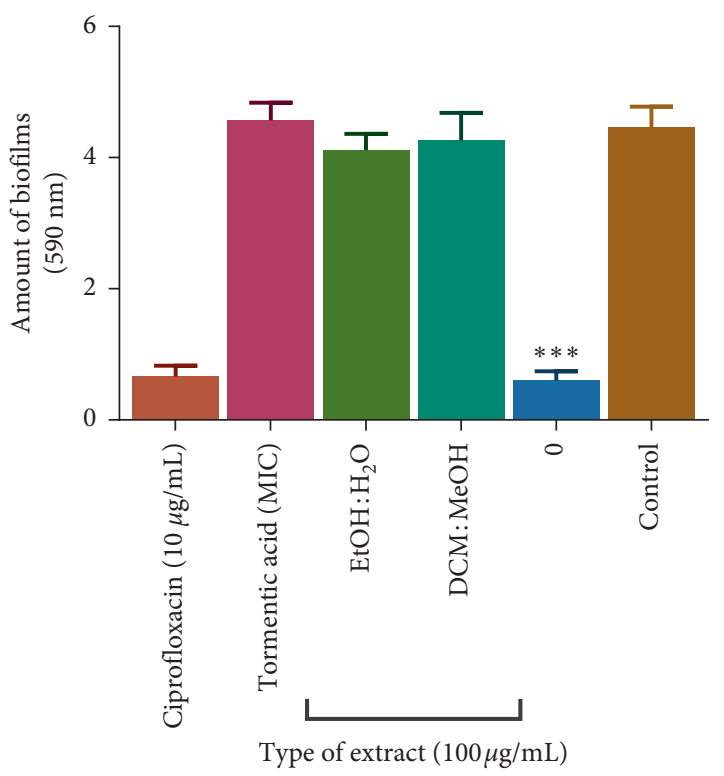

(b)

Figure 5: The effect of ciprofloxacin, tormentic acid congener, and C. viminalis extracts on S pyogenes (a) and A. baumannii (b) biofilm production, respectively. The bacterial strains were incubated together with the test agents for 72 hours, and the formed biofilm was quantified using $0.1 \%$ crystal violet. Ciprofloxacin inhibited the formation of biofilms in both bacteria, whilst tormentic acid congener and C. viminalis extracts showed no significant inhibitory effect. Asterisk denotes a significant difference $\left({ }^{* * *} P<0.0001\right)$.

The hydrophobic property of bacterial surfaces is a major determinant in the adhesion of bacteria and the formation and stabilisation of biofilms by bacteria on animate and inanimate surfaces [56]. Nandu et al., established that fukugiside, a biflavonoid isolated from the leaves of Garcinia travancorica, reduced the cell surface hydrophobicity of S. pyogenes as a mechanism of its antibiofilm activity [55]. Therefore, tormentic acid congener could also be reducing the hydrophobicity of the cell surface of $S$. pyogenes thus causing the detachment of already formed biofilms. It has also been suggested by Lim and colleagues that the detachment of biofilms could be as a result of reduced adhesive forces in the biofilms due to increased solubility of bacterial exopolysaccharides [56]. Tormentic acid congener and 50\% v/v EtOH: $\mathrm{H}_{2} \mathrm{O}$ extract of $C$. viminalis disrupted the biofilm architecture $S$. pyogenes and A. baumannii, respectively. 


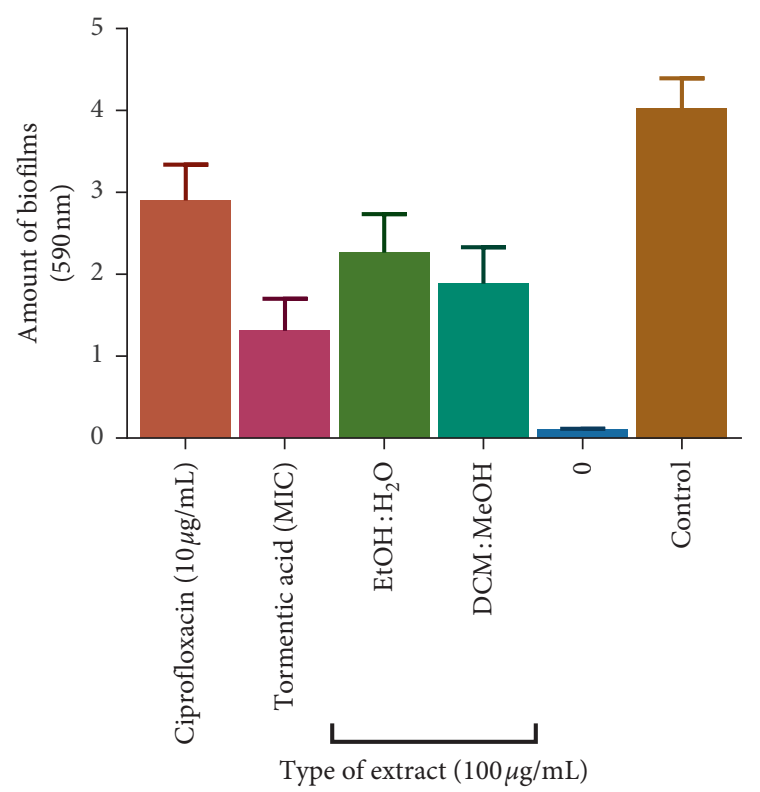

(a)

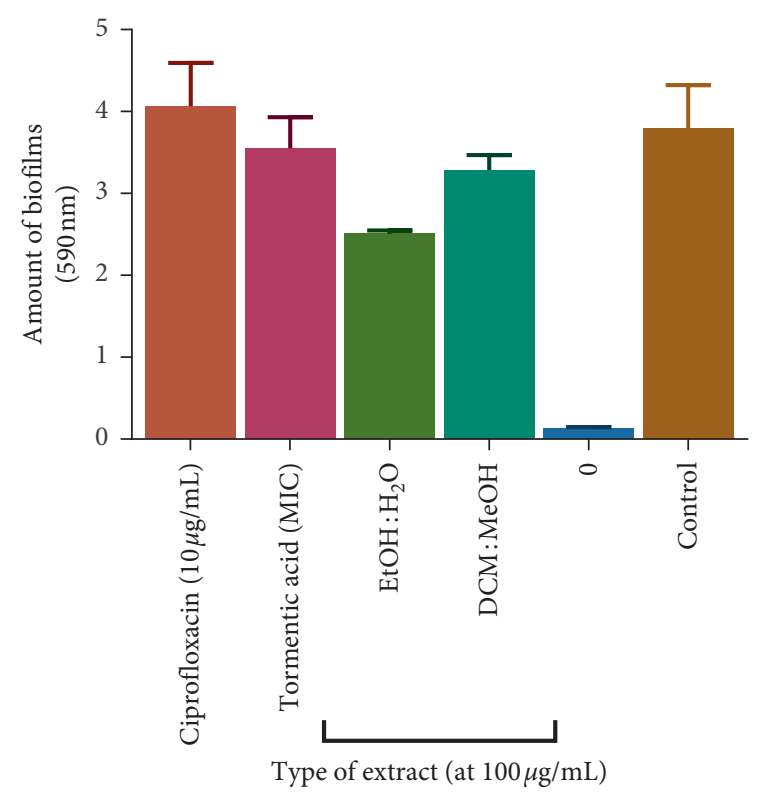

(b)

FIgURE 6: The effect of ciprofloxacin, tormentic acid congener, and C. viminalis extracts on biofilm detachment in S. pyogenes (a) and A. baumannii (b). Ciprofloxacin showed less effect on preformed biofilms than C. viminalis extracts and tormentic acid congener. Tormentic acid congener caused detachment of biofilms in S. pyogenes more than other agents, whilst the EtOH extract of C. viminalis had the greatest effect in A. baumannii.

3.6.2. Effect of Tormentic Acid Congener on Extracellular DNA Production in Biofilms. Most bacteria exist within biofilms encased in an extracellular polymeric substance made up of biopolymers [57]. This present study investigated the antibacterial effects of tormentic acid congener and different $C$. viminalis crude extracts as well as the inhibition of extracellular polysaccharide production against $S$. aureus and $P$. aeruginosa. The results for the effects of the extracts and tormentic acid congener on the production of extracellular DNA from $P$. aeruginosa (Figure 7(a)) and S. aureus (Figure 7(b)) are shown. Ciprofloxacin, extracts, and tormentic acid congener reduced extracellular DNA production in the biofilms. As shown in Figure 7(a), ciprofloxacin reduced significantly more the extracellular DNA produced by $P$. aeruginosa compared to tormentic acid congener and the crude extracts. Tormentic acid congener does, however, significantly reduced extracellular DNA more than the crude extracts. The EtOH: $\mathrm{H}_{2} \mathrm{O}$ extract was more potent than the DCM:MeOH extract in reducing extracellular DNA in $P$. aeruginosa biofilms. Data in Figure 7(b) show that ciprofloxacin and tormentic acid congener had similar effects on extracellular DNA formed by $S$. aureus biofilms as those shown with $P$. aeruginosa. The DCM:MeOH was, however, more potent than the EtOH: $\mathrm{H}_{2} \mathrm{O}$ extract in reducing extracellular DNA in $S$. aureus biofilms.

Extracellular DNA (eDNA) was observed to be abundant in the biofilm matrix as shown in a study by Flemming et al. [58]. A study by Tang et al. showed that eDNA had many functions such as the initial attachment of biofilms of P. aeruginosa, Reinheimera, Microbacterium, and Serratia species [59]. Due to the complex structure of the biofilm, eDNA may provide inherent resistance to antimicrobial agents. The search for an effective drug to eradicate the biofilms or inhibit their growth by targeting the inhibition of eDNA is of importance. Our results showed that the amounts of extracellular DNA produced by $S$. aureus and $P$. aeruginosa strains were significantly inhibited by tormentic acid congener and $C$. viminalis crude extracts.

\subsubsection{Effects of Tormentic Acid Congener on Capsular} Polysaccharide Production. Polysaccharides act as molecular glue in biofilm formation so the reduction in polysaccharide production implies a reduction in biofilm formation and thus provides a possible alternative to killing or inhibition of the growth of pathogenic bacteria [60]. In order to determine if tormentic acid congener, ciprofloxacin, DCM: $\mathrm{MeOH}$ extract, and EtOH: $\mathrm{H}_{2} \mathrm{O}$ extracts had any effect on the formation of biofilms in $P$. aeruginosa and $S$. aureus, the capsular polysaccharide production was quantified after exposure to these samples. The EtOH: $\mathrm{H}_{2} \mathrm{O}$ extract showed the most significant reduction in polysaccharide formation when compared to the reductions caused by tormentic acid congener and DCM:MeOH extract (Figure 8). The EtOH: $\mathrm{H}_{2} \mathrm{O}$ extract was more potent than the DCM:MeOH extract in reducing polysaccharide production in $P$. aeruginosa biofilms (Figure 8(a)). The DCM:MeOH showed more potency in reducing polysaccharide production than the EtOH: $\mathrm{H}_{2} \mathrm{O}$ extract in $\mathrm{S}$. aureus (Figure 8(b)). All antibacterial test agents reduced the extracellular polysaccharide content in S. pyogenes biofilms (Figure 9).

Bacteria in biofilms have been shown to produce extracellular polysaccharides (EPS) which help them to bind the biofilm together in a matrix while anchoring it to 


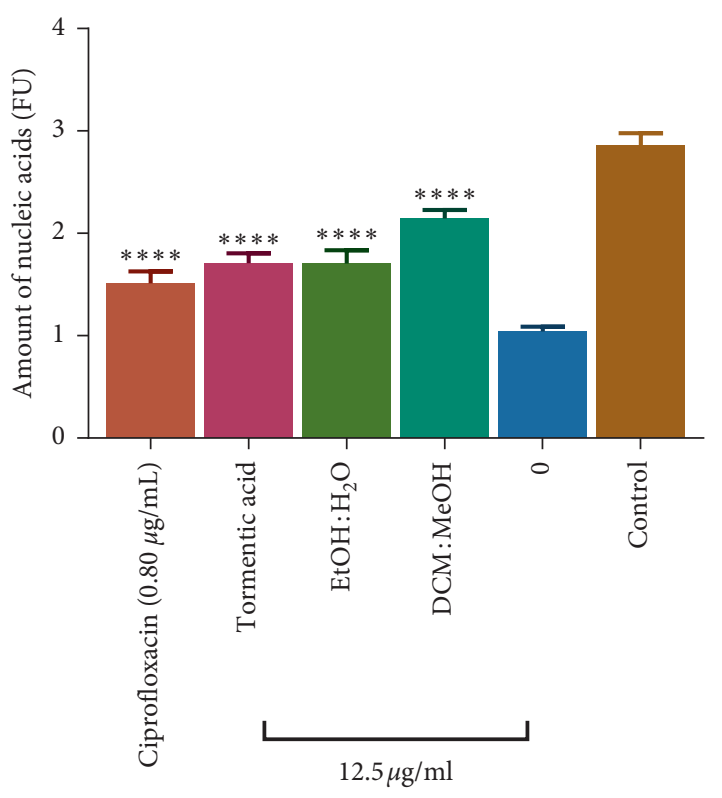

(a)

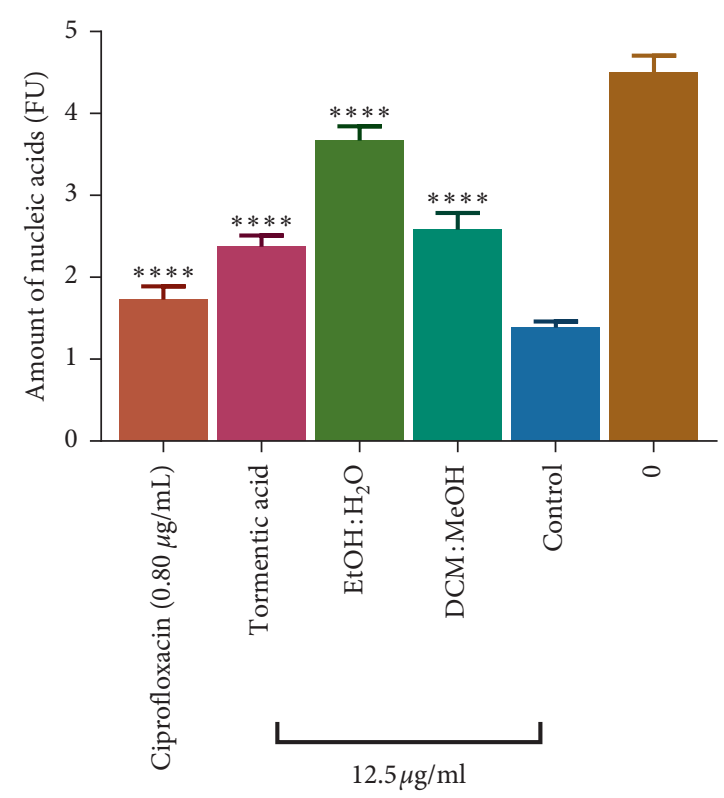

(b)

Figure 7: The effect of C. viminalis EtOH: $\mathrm{H}_{2} \mathrm{O}$ extract, DCM:MeOH extract, tormentic acid congener, and ciprofloxacin on extracellular DNA produced by $P$. aeruginosa (a) and $S$. aureus (b). Cells were incubated in a medium containing $0.80 \mu \mathrm{g} / \mathrm{ml}$ ciprofloxacin as well as $12.5 \mu \mathrm{g} / \mathrm{ml}$ of the crude extracts and tormentic acid congener for $72 \mathrm{~h}$. The amount of extracellular DNA present was determined by staining the biofilms with propidium iodide and spectrophotometrically measuring the amount of dye. These are results after a 24 well plate was washed with phosphate-buffered saline. ANOVA was carried out using GraphPad Prism6 and Dunnett's multiple comparisons test with a summary of ${ }^{* * *} P$ value $<0.0001$. Ciprofloxacin, tormentic acid congener, and extracts reduced extracellular DNA production in $P$. aeruginosa and $S$. aureus biofilms.

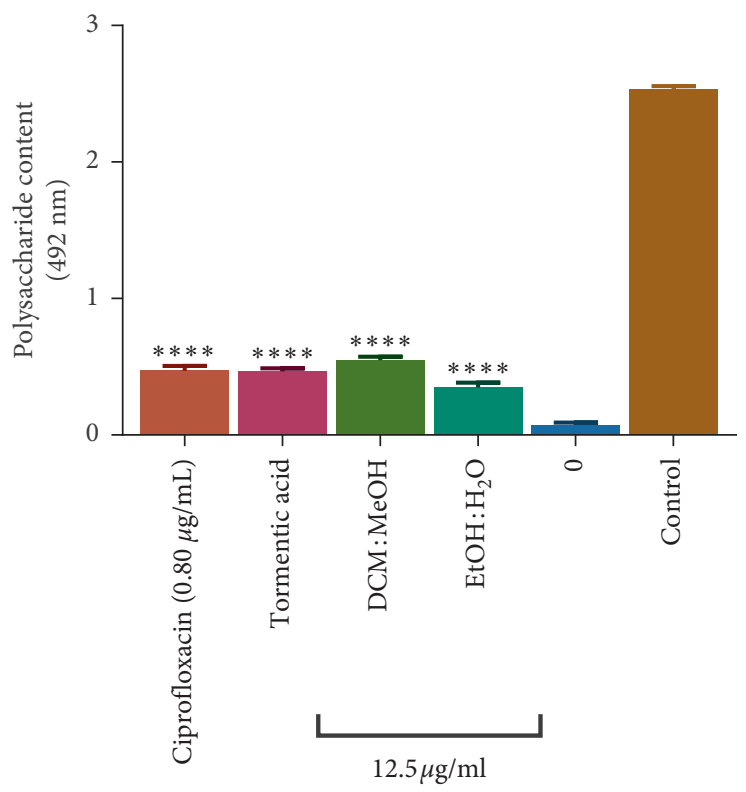

(a)

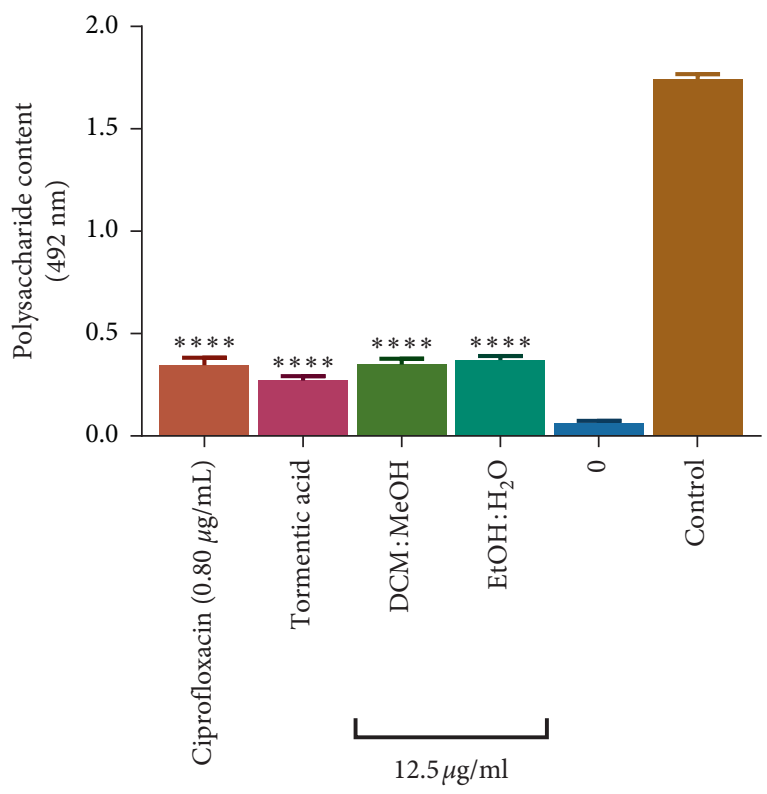

(b)

Figure 8: The effect of C. viminalis EtOH: $\mathrm{H}_{2} \mathrm{O}$ extract, DCM:MeOH extract, tormentic acid congener, and ciprofloxacin on biofilm polysaccharide content. P. aeruginosa (a) and S. aureus (b) were incubated in a medium containing $0.80 \mu \mathrm{g} / \mathrm{ml} \mathrm{ciprofloxacin} \mathrm{and} 12.5 \mu \mathrm{g} / \mathrm{ml}$ of extracts and tormentic acid congener for 16 hours. Mannose was used as the standard for carbohydrate content. Carbohydrate content was read at $492 \mathrm{~nm}$ using a Stat Fax model microplate reader. ANOVA was carried out using GraphPad Prism6 and Dunnett's multiple comparisons test with a summary of ${ }^{* * *} P$ value $<0.0001$. 


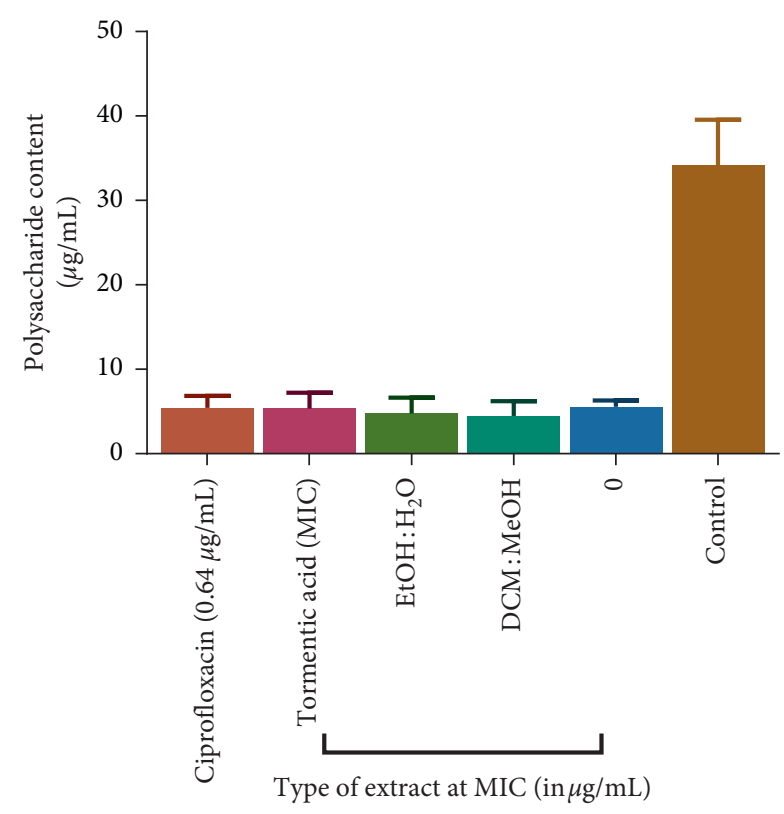

Figure 9: The effect of ciprofloxacin, tormentic acid congener, and C. viminalis extracts on extracellular polysaccharide content in S. pyogenes. Quantification of extracellular polysaccharide content of $S$. pyogenes was performed using the $5 \%$ phenol saturated sulphuring acid test and collection and measuring of the supernatant. All test agents inhibited the formation of capsular exopolysaccharides in $S$. pyogenes.

surfaces [61]. For this study, it is interesting to note that EPS production is significantly reduced for both Gram-positive and Gram-negative pathogens in the presence of tormentic acid congener and different $C$. viminalis crude extracts. This presents a result that has some importance for the possible use of tormentic acid congener as a biofilm control agent. The regulation of EPS production has been studied well for both Gram-positive and Gram-negative pathogens. In a study by Olofsson et al. [62], it was shown that Gramnegative bacteria extracellular polysaccharide production is inhibited directly or indirectly due to naturally occurring antibacterial agents. Similar findings of reduction of EPS against Gram-positive pathogens were reported for the methanol leaf extract fraction of Mangifera indica [63]. Our results also demonstrate a reduction in EPS production after exposure to plant extract, thus resulting in inhibition of biofilm production. This study showed that exposing in $S$. aureus and $P$. aeruginosa to tormentic acid congener and extracts from C. viminalis results in decreases in EPS and eDNA production which may result in decrease in biofilm formation.

\section{Conclusion}

C. viminalis extracts had antibacterial activity against $P$. aeruginosa, $S$. aureus, S. pyogenes, $K$. pneumoniae, and A. baumannii. Extracts of C. viminalis reduced polysaccharide production and extracellular DNA production in $P$. aeruginosa and $S$. aureus biofilms. Tormentic acid congener caused significant cell lysis in $P$. aeruginosa cells. Exposure to tormentic acid congener produced detachment of $S$. pyogenes biofilms well as it reduced the extracellular polysaccharide content of $S$. pyogenes biofilms. However, tormentic acid congener and both $C$. viminalis extracts did not show significant antibacterial activity and antibiofilm formation activity against $A$. baumannii. Tormentic acid congener and extracts of $C$. viminalis, thus, had significant antibacterial and antibiofilm activities on selected ESKAPE bacteria and can act as source lead compounds for the development of antibacterial triterpenoids.

\section{Data Availability}

The datasets used and/or analysed during the current study are available from the corresponding author upon request.

\section{Conflicts of Interest}

The authors declare that they have no conflicts of interest.

\section{Acknowledgments}

The authors acknowledge the assistance of Mr Christopher Chapano, a taxonomist with the National Herbarium and Botanical Gardens, Harare, Zimbabwe, in the authentication of the plant sample names. Support from Swedish International Development Agency through the International Science Programmes (ISP IPICS: ZIM01), Uppsala University, Uppsala, Sweden, is acknowledged. ISP IPICS: ZIM01 supported the research under the title "Biomolecular Interactions Analyses." Support from the Alliance for Global Health and Science (CEND: small grants, Zimbabwe) University of California, Berkeley, is also acknowledged.

\section{References}

[1] Y. Ramsamy, S. Y. Essack, B. Sartorius, M. Patel, and K. P. Mlisana, "Antibiotic resistance trends of ESKAPE pathogens in Kwazulu-Natal, South Africa: a five-year retrospective analysis," African Journal of Laboratory Medicine, vol. 7, no. 2, pp. 1-8, 2018.

[2] J. M. Pogue, K. S. Kaye, D. A. Cohen, and D. Marchaim, "Appropriate antimicrobial therapy in the era of multidrugresistant human pathogens," Clinical Microbiology and Infection, vol. 21, no. 4, pp. 302-312, 2015.

[3] T. Strateva and D. Yordanov, "Pseudomonas aeruginosa-a phenomenon of bacterial resistance," Journal of Medical Microbiology, vol. 58, no. 9, pp. 1133-1148, 2009.

[4] M. Bassetti, A. Vena, A. Croxatto, E. Righi, and B. Guery, "How to manage Pseudomonas aeruginosa infections," Drugs in Context, vol. 7, 2018.

[5] S. A. Riquelme, D. Ahn, and A. Prince, "Pseudomonas aeruginosa and Klebsiella pneumoniae adaptation to innate immune clearance mechanisms in the lung," Journal of Innate Immunity, vol. 10, no. 5-6, pp. 442-454, 2018.

[6] J. L. Veesenmeyer, A. R. Hauser, T. Lisboa, and J. Rello, "Pseudomonas aeruginosa virulence and therapy: evolving translational strategies," Critical Care Medicine, vol. 37, no. 5, p. 1777, 2009.

[7] S. Vasaikar, L. Obi, I. Morobe, and M. Bisi-Johnson, "Molecular characteristics and antibiotic resistance profiles of Klebsiella isolates in Mthatha, Eastern Cape province, South Africa," International Journal of Microbiology, vol. 2017, 2017. 
[8] V. Sarojamma and V. Ramakrishna, "Prevalence of ESBLproducing Klebsiella pneumoniae isolates in tertiary care hospital," ISRN Microbiology, vol. 2011, 2011.

[9] S. Navon-Venezia, K. Kondratyeva, and A. Carattoli, "Klebsiella pneumoniae: a major worldwide source and shuttle for antibiotic resistance," FEMS Microbiology Reviews, vol. 41, no. 3, pp. 252-275, 2017.

[10] M. Zapotoczna, E. O’Neill, and J. P. O'Gara, “Untangling the diverse and redundant mechanisms of Staphylococcus aureus biofilm formation," PLoS Pathogens, vol. 12, no. 7, 2016.

[11] S. S. Wong and K.-Y. Yuen, "Streptococcus pyogenesand reemergence of scarlet fever as a public health problem," Emerging Microbes \& Infections, vol. 1, no. 1, pp. 1-10, 2012.

[12] T. Fiedler, T. Köller, and B. Kreikemeyer, "Streptococcus pyogenes biofilms-formation, biology, and clinical relevance," Frontiers in Cellular and Infection Microbiology, vol. 5, p. 15, 2015.

[13] V. Rubio-López, S. Valdezate, D. Álvarez et al., "Molecular epidemiology, antimicrobial susceptibilities and resistance mechanisms of Streptococcus pyogenes isolates resistant to erythromycin and tetracycline in Spain (1994-2006)," BMC Microbiology, vol. 12, no. 1, p. 215, 2012.

[14] M. Alsan and M. Klompas, "Acinetobacter baumannii: an emerging and important pathogen," Journal of Clinical Outcomes Management: JCOM, vol. 17, no. 8, p. 363, 2010.

[15] Q. Yang, G. S. Schultz, and D. J. Gibson, “A surfactant-based dressing to treat and prevent Acinetobacter baumannii biofilms," Journal of Burn Care \& Research, vol. 39, no. 5, pp. 766-770, 2018.

[16] J. W. Costerton, G. G. Geesey, and K.-J. Cheng, "How bacteria stick," Scientific American, vol. 238, no. 1, pp. 86-95, 1978.

[17] B. Mishra and G. Wang, "Individual and combined effects of engineered peptides and antibiotics on Pseudomonas aeruginosa biofilms," Pharmaceuticals, vol. 10, no. 3, p. 58, 2017.

[18] B. Zatorska, C. R. Arciola, N. Haffner, L. Segagni Lusignani, E. Presterl, and M. Diab-Elschahawi, "Bacterial extracellular DNA production is associated with outcome of prosthetic joint infections," BioMed Research International, vol. 2018, 2018.

[19] Z. Shu, N. Xing, Q. Wang et al., "Antibacterial and anti-inflammatory activities of Physalis alkekengi var. franchetii and its main constituents," Evidence-Based Complementary and Alternative Medicine, vol. 2016, p. 10, Article ID 4359394, 2016.

[20] C. Ramalhete, G. Spengler, A. Martins et al., "Inhibition of efflux pumps in meticillin-resistant Staphylococcus aureus and Enterococcus faecalis resistant strains by triterpenoids from Momordica balsamina," International Journal of Antimicrobial Agents, vol. 37, no. 1, p. 70, 2011.

[21] S. Das and U. Singh, "Therapeutic potentials of Callistemon lanceolatus DC," International Journal of Advances in Pharmacy, Biology and Chemistry, vol. 1, no. 2, pp. 206-210, 2012.

[22] M. Z. M. Salem, M. EL-Hefny, R. A. Nasser, H. M. Ali, N. A. El-Shanhorey, and H. O. Elansary, "Medicinal and biological values of Callistemon viminalis extracts: history, current situation and prospects," Asian Pacific Journal of Tropical Medicine, vol. 10, no. 3, pp. 229-237, 2017.

[23] M. Ramezanian, S. J. Ashraf Mansuri, and A. A. Minaeifar, "Evaluation of the drug synergistic and antibacterial effects of methanol extracts of Callistemon viminalis on some urinary tract infection bacteria," Advanced Herbal Medicine, vol. 2, no. 4, pp. 13-21, 2016.

[24] C. H. Delahaye, L. Rainford, A. Nicholson, S. Mitchell, J. Lindo, and M. Ahmad, "Antibacterial and antifungal analysis of crude extracts from the leaves of Callistemon viminalis," Journal of Medical and Biological Sciences, vol. 3, no. 1, pp. 1-7, 2009.

[25] F. F. V. Evaristo, M. R. J. R. Albuquerque, H. S. dos Santos et al., "Antimicrobial effect of the triterpene $3 \beta, 6 \beta, 16 \beta$ trihydroxylup-20 (29)-ene on planktonic cells and biofilms from Gram positive and Gram negative bacteria," BioMed Research International, vol. 2014, 2014.

[26] A. G. Pacheco, A. F. C. Alcântara, V. G. C. Abreu, and G. M. Corrêa, Relationships between Chemical Structure and Activity of Triterpenes against Gram-Positive and GramNegative Bacteria. A Search for Antibacterials Agents, InTech, Rijeka, Croatia, 2012.

[27] M. R. Loizzo, M. Bonesi, N. G. Passalacqua, A. Saab, F. Menichini, and R. Tundis, "Antiproliferative activities on renal, prostate and melanoma cancer cell lines of Sarcopoterium spinosum aerial parts and its major constituent tormentic acid," Anti-Cancer Agents in Medicinal Chemistry, vol. 13, no. 5, pp. 768-776, 2013.

[28] X. Lin, S. Zhang, R. Huang et al., "Protective effect of tormentic acid from Potentilla chinensis against lipopolysaccharide/D-galactosamine induced fulminant hepatic failure in mice," International Immunopharmacology, vol. 19, no. 2, pp. 365-372, 2014.

[29] A. Vipra, S. N. Desai, R. P. Junjappa et al., "Determining the minimum inhibitory concentration of bacteriophages: potential advantages," Advances in Microbiology, vol. 3, no. 2, p. 10, Article ID 32359, 2013.

[30] J. J. Martinez-Irujo, M. L. Villahermosa, E. Alberdi, and E. Santiago, "A checkerboard method to evaluate interactions between drugs," Biochemical Pharmacology, vol. 51, no. 5, pp. 635-644, 1996.

[31] G. Orhan, A. Bayram, Y. Zer, and I. Balci, "Synergy tests by E test and checkerboard methods of antimicrobial combinations against Brucella melitensis," Journal of Clinical Microbiology, vol. 43, no. 1, pp. 140-143, 2005.

[32] J. Meletiadis, S. Pournaras, E. Roilides, and T. J. Walsh, "Defining fractional inhibitory concentration index cutoffs for additive interactions based on self-drug additive combinations, Monte Carlo simulation analysis, and in vitro-in vivo correlation data for antifungal drug combinations against Aspergillus fumigatus," Antimicrobial Agents and Chemotherapy, vol. 54, no. 2, pp. 602-609, 2010.

[33] S. P. Hawser and L. J. Douglas, "Biofilm formation by Candida species on the surface of catheter materials in vitro," Infection and Immunity, vol. 62, no. 3, pp. 915-921, 1994.

[34] S. Taniguchi, Y. Imayoshi, E. Kobayashi et al., "Production of bioactive triterpenes by Eriobotrya japonica calli," Phytochemistry, vol. 59, no. 3, pp. 315-323, 2002.

[35] M. Stavri, L. J. V. Piddock, and S. Gibbons, "Bacterial efflux pump inhibitors from natural sources," Journal of Antimicrobial Chemotherapy, vol. 59, no. 6, pp. 1247-1260, 2007.

[36] T. A. Chitemerere and S. Mukanganyama, "In vitro antibacterial activity of selected medicinal plants from Zimbabwe," The African Journal of Plant Science and Biotechnology, vol. 5, no. 1, pp. 1-7, 2011.

[37] V. Tiwari, R. Roy, and M. Tiwari, "Antimicrobial active herbal compounds against Acinetobacter baumannii and other pathogens," Frontiers in Microbiology, vol. 6, p. 618, 2015.

[38] D. D. Orhan, B. Özçelik, S. Özgen, and F. Ergun, "Antibacterial, antifungal, and antiviral activities of some flavonoids," Microbiological Research, vol. 165, no. 6, pp. 496-504, 2010.

[39] A. E. Green, R. S. Rowlands, R. A. Cooper, and S. E. Maddocks, "The effect of the flavonol morin on adhesion 
and aggregation of Streptococcus pyogenes," FEMS Microbiology Letters, vol. 333, no. 1, pp. 54-58, 2012.

[40] S. Perumal, R. Mahmud, and N. Mohamed, "Combination of epicatechin 3-gallate from Euphorbia hirta and cefepime promotes potential synergistic eradication action against resistant clinical isolate of Pseudomonas aeruginosa," Evidence-Based Complementary and Alternative Medicine, vol. 2018, 2018.

[41] D. Dundar and M. Otkun, "In-vitro efficacy of synergistic antibiotic combinations in multidrug resistant Pseudomonas aeruginosa strains," Yonsei Medical Journal, vol. 51, no. 1, pp. 111-116, 2010.

[42] F. Nazzaro, F. Fratianni, L. De Martino, R. Coppola, and V. De Feo, "Effect of essential oils on pathogenic bacteria," Pharmaceuticals, vol. 6, no. 12, pp. 1451-1474, 2013.

[43] D. Penduka, N. Gasa, M. Hlongwane, R. Mosa, F. Osunsanmi, and A. Opoku, "The antibacterial activities of some plantderived triterpenes," African Journal of Traditional, Complementary and Alternative Medicines, vol. 12, no. 6, pp. 180-188, 2015.

[44] Y.-L. Wang, G.-Y. Sun, Y. Zhang, J.-J. He, S. Zheng, and J.-N. Lin, "Tormentic acid inhibits $\mathrm{H}_{2} \mathrm{O}_{2}$-induced oxidative stress and inflammation in rat vascular smooth muscle cells via inhibition of the NF- $\kappa \mathrm{B}$ signaling pathway," Molecular Medicine Reports, vol. 14, no. 4, pp. 3559-3564, 2016.

[45] P. Chung, P. Navaratnam, and L. Chung, "Synergistic antimicrobial activity between pentacyclic triterpenoids and antibiotics against Staphylococcus aureus strains," Annals of Clinical Microbiology and Antimicrobials, vol. 10, no. 1, p. 25, 2011.

[46] H. Jedrey, K. S. Lilley, and M. Welch, "Ciprofloxacin binding to GyrA causes global changes in the proteome of Pseudomonas aeruginosa," FEMS Microbiology Letters, vol. 365, no. 13, 2018.

[47] S. D. Cox and J. L. Markham, "Susceptibility and intrinsic tolerance ofPseudomonas aeruginosato selected plant volatile compounds," Journal of Applied Microbiology, vol. 103, no. 4, pp. 930-936, 2007.

[48] J. C. Lopez-Romero, H. González-Ríos, A. Borges, and M. Simões, "Antibacterial effects and mode of action of selected essential oils components against Escherichia coli and Staphylococcus aureus," Evidence-Based Complementary and Alternative Medicine, vol. 2015, 2015.

[49] T. Ogawa, Y. Terao, H. Okuni et al., "Biofilm formation or internalization into epithelial cells enable Streptococcus pyogenes to evade antibiotic eradication in patients with pharyngitis," Microbial Pathogenesis, vol. 51, no. 1-2, pp. 58-68, 2011.

[50] V. Tiwari, D. Tiwari, V. Patel, and M. Tiwari, "Effect of secondary metabolite of Actinidia deliciosa on the biofilm and extra-cellular matrix components of Acinetobacter baumannii," Microbial Pathogenesis, vol. 110, pp. 345-351, 2017.

[51] L. M. Sanchez, A. T. Cheng, C. J. Warner et al., "Biofilm formation and detachment in Gram-negative pathogens is modulated by select bile acids," PloS One, vol. 11, no. 3, 2016.

[52] G. A. Subramenium, K. Vijayakumar, and S. K. Pandian, "Limonene inhibits streptococcal biofilm formation by targeting surface-associated virulence factors," Journal of Medical Microbiology, vol. 64, no. 8, pp. 879-890, 2015.

[53] N. Irani, E. Basardeh, F. Samiee et al., "The inhibitory effect of the combination of two new peptides on biofilm formation by Acinetobacter baumannii," Microbial Pathogenesis, vol. 121, pp. 310-317, 2018.
[54] J. W. Costerton, Z. Lewandowski, D. E. Caldwell, D. R. Korber, and H. M. Lappin-Scott, "Microbial biofilms," Annual Review of Microbiology, vol. 49, no. 1, pp. 711-745, 1995.

[55] T. G. Nandu, G. A. Subramenium, S. Shiburaj et al., "Fukugiside, a biflavonoid from Garcinia travancorica inhibits biofilm formation of Streptococcus pyogenes and its associated virulence factors," Journal of Medical Microbiology, vol. 67, no. 9, pp. 1391-1401, 2018.

[56] J. H. Lim, S.-H. Song, H.-S. Park, J. R. Lee, and S. M. Lee, "Spontaneous detachment of Streptococcus mutans biofilm by synergistic effect between zwitterion and sugar alcohol," Scientific Reports, vol. 7, 2017.

[57] R. Thenmozhi, P. Nithyanand, J. Rathna, and S. Karutha Pandian, "Antibiofilm activity of coral-associated bacteria against different clinical $\mathrm{M}$ serotypes ofStreptococcus pyogenes," FEMS Immunology \& Medical Microbiology, vol. 57, no. 3, pp. 284-294, 2009.

[58] H.-C. Flemming, T. R. Neu, and D. J. Wozniak, "The EPS matrix: the "house of biofilm cells," Journal of Bacteriology, vol. 189, no. 22, pp. 7945-7947, 2007.

[59] L. Tang, A. Schramm, T. R. Neu, N. P. Revsbech, and R. L. Meyer, "Extracellular DNA in adhesion and biofilm formation of four environmental isolates: a quantitative study," FEMS Microbiology Ecology, vol. 86, no. 3, pp. 394-403, 2013.

[60] C. Fuqua, M. R. Parsek, and E. P. Greenberg, "Regulation of gene expression by cell-to-cell communication: acyl-homoserine lactone quorum sensing," Annual Review of Genetics, vol. 35, no. 1, pp. 439-468, 2001.

[61] B. E. Christensen, "The role of extracellular polysaccharides in biofilms," Journal of Biotechnology, vol. 10, no. 3-4, pp. 181-202, 1989.

[62] A.-C. Olofsson, M. Hermansson, and H. Elwing, "N-acetyl-Lcysteine affects growth, extracellular polysaccharide production, and bacterial biofilm formation on solid surfaces," Applied and Environmental Microbiology, vol. 69, no. 8, pp. 4814-4822, 2003.

[63] F. M. Husain, I. Ahmad, A. S. Al-thubiani, H. H. Abulreesh, I. M. AlHazza, and F. Aqil, "Leaf extracts of Mangifera indica L. Inhibit quorum sensing-regulated production of virulence factors and biofilm in test bacteria," Frontiers in Microbiology, vol. 8, p. 727, 2017. 